\title{
Ortaokul Matematik Öğretmeni Adaylarının Matematik Öğretimi İçin Tasarladıkları Oyunların Farklı Açılardan Ele Alınması*
}

\author{
Analysis of Games Designed by the Secondary School Pre-Service \\ Mathematics Teachers
}

\author{
Tuğba BARAN KAYA ${ }^{1}$, Tuba GÖKÇEK ${ }^{2}$
}

${ }^{1}$ Sorumlu Yazar, Dr. Arș. Gör., Matematik ve Fen Bilimleri Eğitimi Bölümü, Eğitim Fakültesi, Kırlkkale Üniversitesi, Türkiye, tugbabaran@kku.edu.tr, (https://orcid.org/0000-0001-99244352)

2 Prof. Dr., Matematik ve Fen Bilimleri Eğitimi Bölümü, Ĕgitim Fakültesi, Kırıkkale Üniversitesi, Türkiye, tubagokcek@kku.edu.tr, (https://orcid.org/0000-0003-2923-070X)

Geliş Tarihi: 05.07.2021

Kabul Tarihi: 08.10.2021

\section{ÖZ}

Bu araştırmada "Oyunla Matematik Öğretimi” dersini almış olan İlköğretim Matematik Öğretmenliği Anabilim Dalı öğrencilerinden matematik derslerinde kullanılabilecek oyunlar tasarlamaları istenmiştir. Araştırma için oyun tasarlamaya gönüllü 38 öğrencinin oyunları, oyun türleri, oyunun oynandığı mekan, sınıf seviyesi, öğrenme alanı, pekiştirme veya öğretim amaçlı olması, oyuncu sayısı bakımından sınıflandırılmıştır. Bu sınıflandırma yapılırken betimsel analiz tekniğinden faydalanılmıştır. Verilerin depolanması ve analizi MAXQDA Analytics Pro 2018 programı üzerinde yapılmış ve veriler MAXQDA haritaları şeklinde sunulmuştur. Ayrıca kategorilere ilişkin oyun örnekleri sunularak, bu oyunların matematik öğretimine kazandırılması hedeflenmiştir. Araştırmanın sonuçlarına bakıldığında oyunların neredeyse tamamının pekiştirme amaçlı olduğu görülmüştür. Oyun türlerine bakıldığında ise oyunların büyük bir çoğunluğunun masa/kart oyunları türünde tasarlandığı ortaya çıkmıştır. Ayrıca diğer sınıf düzeylerine göre 8. sınıf düzeyi için daha az oyun tasarlanmışken, Sayılar ve İşlemler öğrenme alanı oyun tasarlamak için en çok tercih edilen öğrenme alanı olmuştur. Öğretmen adayları çoğunlukla tüm sınıfin katılımını ya da en az 2-3 kişinin katılımını gerektiren oyunlar tasarlamayı tercih etmișlerdir. Oyunların oynanacağı mekan olarak ise öğretmen adaylarının hem sınıf hem de sınıf dışında oynanabilecek oyunlara yöneldikleri söylenebilir.

Anahtar Kelimeler: Oyunla matematik öğretimi, oyun tasarlama, ortaokul matematik öğretmeni adayı.

\begin{abstract}
In this study, the students of the Elementary School Mathematics Teaching Department who took the course "Teaching Mathematics with Games" were asked to design games that can be used in mathematics lessons. The games designed by 38 students were classified in terms of game types, the platform it is played, class level, learning area, teaching purposes, and the number of players. Descriptive analysis technique was used to make this classification through MAXQDA Analytics Pro 2018 program and the data were presented as MAXQDA maps. The results of the study show that all games are designed for teaching purposes. In terms of game types, the majority of the games are designed as board / card games. Less games are designed for the 8th grade level compared to other grade levels. Games are mostly used to
\end{abstract}

\footnotetext{
* Bu çalışma 4-6 Aralık 2020 tarihleri arasında düzenlenen 2. Uluslararası Eğitim Araştırmaları Kongresi’nde bildiri olarak sunulmuş ve özeti “Özet Metin Bildiri Kitabı”nda basılmıştır.
} 
teach number and four operations subjects in maths. The participants mostly preferred to design games that required the participation of the whole class or the participation of at least 2-3 people. In terms of game places, they tend to design games that can be played both indoor and outdoor.

Keywords: Game based mathematics teaching, game design, secondary school teacher candidates of mathematics.

\section{GIRIŞ}

Oyun, oyuncuların ölçülebilir bir şekilde sonuçlanan, kurallara bağlı yapay bir mücadeleye girdiği bir sistemdir (Salen ve Zimmerman, 2003). Kurallar, hedef ve amaçlar, dönütler, mücadele/yarışma içerme, etkileşim, sunum ve hikaye olmak üzere 6 bileşeni olan (Prensky, 2001) oyunun birçok farklı türü olduğunu söylemek mümkündür. Bu türlerden biri olan masa oyunları bir zeminin üzerinde çeşitli materyallerle oynanan ve belli kuralları olan oyunlardır (Bayram, 2015). Masa oyunları, her yaştan insana her konuda uygulamalı olarak beceri ve bilgi gelişimi sağlamak için önemli bir araçtır. İyi tasarlanmış masa oyunları sadece ilgi çekici bir atmosfer yaratmakla kalmaz, aynı zamanda içeriğe odaklanmak ve öğrenmeyi pekiştirmek ve uygulamak için eğlenceli, ancak rekabetçi bir ortam sağlar (Treher, 2011). Bir diğer tür olan eğitsel bilgisayar oyunları, öğrencilerin eğlenirken öğrendikleri, onları motive eden, diğer öğretim tekniklerini zenginleştiren ve onların tamamlayıcısı olan oyunlardır (Çankaya ve Karamete, 2008). Geleneksel oyunlar ise nesilden nesile bir miras olarak aktarılmış kuralları olan oyunlardır. Çocukların gelişimine önemli ölçüde katkıları olan geleneksel oyunlar kimi zaman türkülü, şarkılı, dansl,, tekerlemelidir, kimi zaman bilmecelidir, kimi zamansa oynamak için bazı araçlara ihtiyaç duyulur (Emin, 2019). Yukarıda bahsi geçen oyun türleri dışında spor oyunları, halk oyunları, tiyatro oyunları vb. gibi birçok oyun türü bulunmaktadır. Bir de aslında oyun olmayan içeriklerin tasarımında puan, rozet, liderlik tahtası, ödül gibi oyun elementlerinin kullanıldığı oyunlaştırma kavramı (Deterding, O’Hara, Sicart, Dixon ve Nacke, 2011) karşımıza çıkmaktadır.

Hangi türü olursa olsun oynayan kişinin keyifli zaman geçirmesini sağlayan oyunun, gerek çocuklar gerekse yetişkinler için bir eğlence aracı olarak görülmesine rağmen, özellikle çocuğun ayrılmaz bir parçası olduğunu söylemek mümkündür (Çavuş, Kulak, Berk ve Öztuna Kaplan, 2011). Nasıl ki bir çocuğun bedensel ve ruhsal gelişimi için sağlıklı beslenmesi ve uyuması gerekiyorsa, yeteri kadar oyun oynaması da gerekmektedir. Kaldı ki oyun oynamak çocuğun kendini ve yeteneklerini keşfetmesine, paylaşımcı biri olmasına da katkıda bulunur (Başün ve Doğan, 2020). Bunlar dışında da birçok bilgi ve becerinin farkında olmadan oyun içinde kazanıldığı bilinmektedir (Girmen, 2012). Bu becerilerden bazıları grupla karar alma, sayılarla işlem yapma, planlama, stratejik hareket etme, iletişim kurma, sorgulama, veri işleme vs.'dir (Kirriemur ve McFarlane, 2004). Ayrıca oyunun çocukların dikkatlerini geliştirdiğine dair kanıtlar sunan araştırmalar da bulunmaktadır (Akandere, 2006; Orhan, 2018). Elbette oyunların katkılarını sadece bilgi ve beceri bakımından düşünmemek gerekir. Oyunların duyuşsal ve psikomotor açıdan da katkıları olduğu bilinmektedir (Ulutaş, 2011). Durkin ve Barber (2002) oyun oynayan ergenlerin ailelerine yakın ilişki kurma, okula bağlılık, boş zaman faaliyetlerine katılım, zihinsel sağlığı pozitif yönde etkilemesi, madde kullanımı, benlik kavramı, arkadaşlık kurma ve ebeveynlere bağlılık açısından daha olumlu sonuçlara sahip oldukları sonucuna ulaşmıştır. Davranışsal boyutta yaklaşıldığında okul öncesi ve ilkokul seviyesindeki öğrenciler daha çok psikomotor özelliklerin ön planda olduğu oyunlar oynarlarken, sonrasında bilişsel özelliklerin önem kazandığı oyunlar ön plana çıkmaktadır (Gürbüz, Gülburnu ve Şahin, 2017).

Çocuklar için sayısız faydasının yanında, öğretim niteliğine sahip olarak tasarlanan oyunların sınıf ortamında öğretmen ve öğrencilere önemli katkılar sağladığ 1 da bilinmektedir (Kablan, 2010). Çünkü oyunlar öğrencilere klasik öğrenme ortamlarında erişimi pek mümkün olmayan kişisel öğrenme deneyimleri sağlar (Vos, Meijden ve Denessen, 2011). Özellikle de 
öğrencilerin en çok zorlandıkları ve korktukları ders olan matematiği oyunla öğretmek, matematiği sevdirmede ve öğretmede etkili olabilir. Ayrıca öğrencilerin matematiğe dair korkularının üstesinden gelmelerinde, ön yargılarını aşmalarında, hatta onları motive etmede de etkili olabilmektedir (Uygun ve Hakkoymaz, 2019). Bunun yanında oyun yoluyla matematiği oluşturan soyut kavramları daha somut hale getirip, çocukların matematiği daha iyi anlayabilmeleri sağlanabilir (Soylu, 2001). Böylece öğrenirken aynı zamanda eğlenceli vakit de geçirmeleri sağlanabilir (Hacısalihoğlu Karadeniz, 2018).

Literatürde oyunla matematik öğretimini ele alan birçok çalışma yer almaktadır. $\mathrm{Bu}$ çalışmalardan bazıları oyunlarla matematik öğretiminin erişiye (Başün ve Doğan, 2020; Beyhan ve Tural, 2007; Biriktir, 2008; Tural, 2005) veya tutuma (Çankaya ve Karamete, 2008; Tural, 2005) olan etkisini ele alırken, bazıları oyunlara dair öğrenci (Başün ve Doğan, 2017; Şahin, 2016), öğretmen (Doğan ve Sönmez, 2019; Gürbüz, Gülburnu ve Şahin, 2017; Özata ve Çoşkuntuncel, 2019), öğrenci-öğretmen (Duran ve Kaplan, 2014) veya öğretmen adaylarının (Saygı ve Alkaş Ulusoy, 2019; Topçu, Küçük ve Göktaş, 2014; Usta vd., 2017; Yıldız Durak, 2019; Yıldız Durak ve Karaoğlan Yılmaz, 2019) görüşlerini incelemiştir. Birçok çalışmada oyunların öğretimde etkili olduğu her ne kadar sıklıkla dile getirilse de, öğretim ortamlarına entegre edilen oyun örnekleri nispeten azdır (Linehan, Kirman, Lawson ve Chan, 2011). Ancak oyunun daha geniş bir disipline nasıl uyacağ kritik bir husustur (de Freitas, 2018). Öyle ki oyunları bir öğretim ortamına entegre etmek sanıldığ 1 kadar kolay değildir. Birçok karmaşık kaynağın düzenlemesini gerektirir (de Freitas, 2018; Marklund ve Alklind Taylor, 2016). Kaldı ki öğretim ortamlarında oynanan her oyunun öğrencilere eğlenceli gelmeyeceği, öğrencilerde katılma isteği uyandırmayacağ 1 ve öğretimi hedefe ulaştırmayacağı da bir gerçektir (Gürbüz, Gülburnu ve Şahin, 2017). Bu düşünceden hareketle bu araştırmada ortaokul matematik öğretmeni adaylarından matematik öğretmek için oyunlar tasarlamaları istenmiştir. Daha sonra tasarladıkları oyunlar oyun türleri, oyunun oynandığı mekan, sınıf seviyesi, öğrenme alanı, pekiştirme veya öğretim amaçlı olması, oyuncu sayısı bakımından sınıflandırılmıştır. Ayrıca araştırmanın amaçlarından biri de ortaokul matematik derslerinde kullanılabilecek oyunlardan örnekler sunabilmektir. Bu amaçla farklı sınıf seviyeleri, oyun türleri, öğrenme alanları, oyunların oynandığı mekanlara ve amaçlarına ilişkin oyun örnekleri sunulmuştur.

\section{YÖNTEM}

Araştırmada nitel araştırma tekniklerinden durum çalışması deseni kullanılmıştır. Durum çalışması süreç, olaylar, kişiler gibi olgulara 1şık tutmak için tercih edilen bir desendir (Creswell, 2013). Bu çalışmada durum çalışması deseni kullanılmasının nedeni genelleme amaçlanmadan, matematik öğretmeni adaylarının derslerinde materyal olarak kullanmak üzere tasarladıkları oyunlara dair zengin bir anlayış sağlayabilmektir.

\subsection{Katılımcilar}

Araştırmanın katılımcılarını İç Anadolu Bölgesi'nde bir üniversitenin "Oyunla Matematik Öğretimi” dersini almış 2. Sınıf öğrencileri oluşturmaktadır. Bu öğrencilerden 31'i kız 7'si erkek öğrencidir. Öğrencilerin genelinin oyunla matematik öğretimi hakkında olumlu tutuma sahip oldukları gözlenmiş ve katılımda gönüllülük esas alınmıştır. Araştırmaya başlamadan önce öğrencilere, dersin sonunda hazırlayacakları oyunların bir araştırmada doküman olarak yer alacağı ve araştırmanın yürütülme biçimi hakkında bilgi verilmiştir. Oyun tasarlama süreci tamamlandıktan sonra ise araştırma bulgularını desteklemek, matematik öğretimine yardımcı oyunları literatüre kazandırmak amacıyla, öğrencilerin hazırlamış oldukları oyunlardan birkaç görsele ve bir paragraflık kısa açıklamalara yer verilmek istendiği, yazılı bir izin belgesi olarak kendilerine sunulmuştur. Ayrıca bu belgede oyunların tamamına araştırmada yer verilmeyeceği ve araştırmanın hiçbir yerinde öğrencilerin isimlerinin geçmeyeceği de belirtilmiştir. Bu 
kapsamda oyunlarının araştırma metninde kullanılmasına onay veren öğrencilerin oyunlarına burada yer verilmiştir.

\subsection{Veri Toplama Aracı}

Araştırmanın dokümanlarını 2019-2020 eğitim döneminde İlköğretim Matematik Öğretmenliği Programının 2. sınıfına devam eden "Oyunla Matematik Öğretimi” dersini almış 38 öğretmen adayının tasarlamış oldukları oyunlar oluşturmaktadır. Bu öğretmen adaylarına bir dönem boyunca Oyunla Matematik Öğretimi dersinde oyunların özellikleri, tasarlanma ilkeleri, matematik öğretimine entegrasyonu, oyun türleri ve örnekleri hakkında dersi yürüten araştırmacılardan biri tarafindan detaylı bilgi verilmiştir. Toplam 12 hafta boyunca hafta hafta işlenen konular "oyun ve oyun türleri (1. Hafta), oyuna yönelik kuramsal yaklaşımlar (2. Hafta), matematik öğretiminde oyunların önemi (3. Hafta), matematiksel kavramların oyunla öğretimi (4-5. Hafta), teknolojik oyunlar ve matematik öğretimi (6. Hafta), matematiğe yönelik oyun tasarlama, uyarlama süreci (7. Hafta), matematik öğretim programı kazanımlarına uyarlanmış çeşitli oyunlardan örnekler (8. Hafta), matematikçiler tarafından geliştirilen bazı oyunların incelenmesi (9. Hafta), zeka oyunları-mantık oyunları (10. Hafta), bulmacalar (11. Hafta), ve oyun teorisi (12. Hafta), 'dir. Öğrencilere oyun tasarımı için gereken detaylı bilgiler ilk 8 hafta verildikten sonra, 5 hafta içinde oyun tasarımlarını tamamlamaları istenmiştir.

\subsection{Verilerin Toplanması ve Analizi}

Oyunla Matematik Öğretimi hakkında detaylı bilgiler verilmesinin ardından öğretmen adaylarından gerek bir kazanımın gerekse bir ünitenin öğretimine yönelik veya alıştırma amaçlı oyunlar tasarlamaları istenmiştir. Katılımcılar oyun türlerinin (geleneksel oyunlar, bilgisayar oyunları, zeka ve strateji oyunları, masa oyunları, oyunlaştırma), sınıf seviyesinin seçimi $(5,6,7$ veya 8. sınıf) konusunda özgür bırakılmıştır. Ayrıca katılımcılardan tasarladıkları oyunların yanı sıra kuralların ve oynanış biçiminin bulunduğu ayrıntılı bir oyun kılavuzu hazırlamaları istenmiştir. Oyunlar grup şeklinde değil bireysel olarak hazırlanmış olup, öğrencilerden 5 hafta içinde oyunlarını tamamlamaları istenmiştir. Öğrenciler hem ilk 8 haftalık öğretim sürecinde, hem de bu 8 haftayı izleyen 5 haftalık oyun tasarlama sürecinde gerektiğinde araştırmacılara danışabilmiş, bu süreçte oyun tasarımlarına müdahale etmeden kendilerine gereken destek sağlanmıştır. Elde edilen veriler betimsel analize tabi tutulmuştur. Analizler yapılırken nitel veri analiz programlarından MAXQDA Analytics Pro 2018 programından faydalanılmıştır. Katılımcılar tarafından tasarlanan oyunlar oyun türleri, sınıf seviyesi, öğrenme alanı ve alt öğrenme alanı, pekiştirme veya öğretim amaçlı olması, öğrencilerin katılım durumu, oyunun oynanacağı mekan açısından kategorize edilmiştir. Kodlamanın güvenirliği açısından verilerin \%20'si diğer araştırmacı tarafından da kodlanmış ve yüksek uyum tespit edilmiştir.

\section{BULGULAR}

Verilerin analizi sonucu elde edilen bulgular aşağıda MAXQDA haritaları yoluyla sunulmuş, her bir kategoriye ilişkin öğretmen adaylarının tasarlamış oldukları oyun örneklerine de yer verilmiştir. Bulgular başlıklar halinde sunulmuştur.

\section{1. Öğretmen Adaylarının Tasarladıkları Oyunların Amacı}

Tasarlanan oyunların pekiştirme veya öğretim amaçlı olmasına göre dağılımına ilişkin veriler Şekil 1'de yer alan MAXQDA haritasında görülmektedir. 


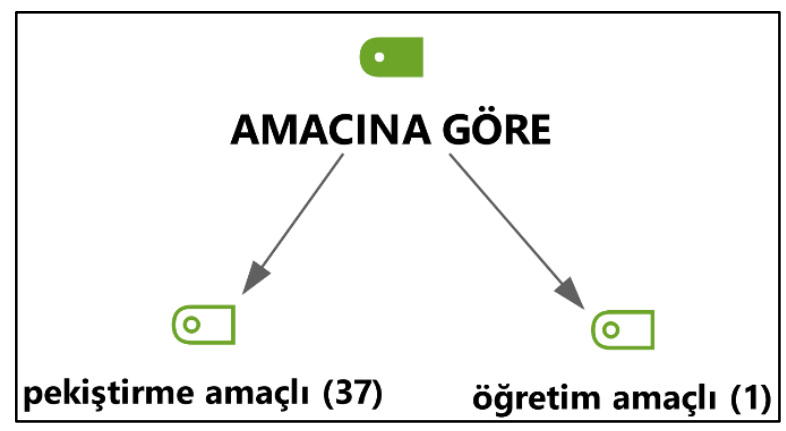

Şekil 1. Öğretmen Adaylarının Tasarlamış Oldukları Oyunların Amacı

Matematik öğretmeni adayları oyunlarını herhangi bir konunun öğretimi veya pekiştirilmesi için tasarlama konusunda özgür bırakılmış, ancak bir öğretmen adayı dışında diğer öğretmen adayları $(\mathrm{f}=37)$ konunun öğretilmesinin ardından pekiştirme amacı güden oyunlar tercih etmişlerdir. Aşağıdaki şekilde (Şekil 2) görseline yer verilen oyun konunun ögretimi sırasında kullanılacak tek oyundur.

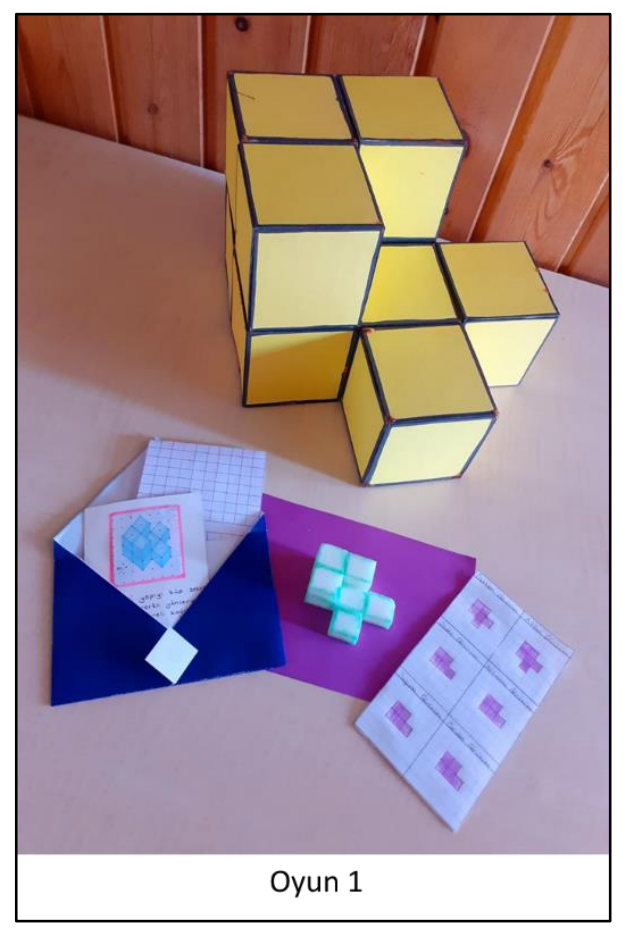

Şekil 2. Konunun Öğretiminde Kullanılacak Oyun

Cisimlerin farklı yönlerden görünümü alt öğrenme alanının öğretimi aşamasında kullanılması hedeflenen "Şekerli küpler" oyununda sınıf, her grupta 4 öğrenci olacak şekilde gruplara ayrılır. Her grup için önceden hazırlanmış her birinde aynı soruların olduğu soru zarfları dağıtılır. Soru zarfları gruplara dağıtıldıktan sonra öğretmen, öğrencilerin ellerindeki soruyu çözmeleri için 120 sn olan süreyi başlatır. Öğretmen adayı öğrencilerin kâğ 1 üzerinde gördükleri yapının farklı yönlerden görünümünü zihinlerinde canlandırmakta zorlanabilecekleri yaklaşımından yola çıkmıştır. Oyun materyalleri olan renkli küpler ve ellerindeki küp şekerler sayesinde yapıyı farklı yönlerden daha rahat görebileceklerini düşünmektedir.

\section{2. Öğretmen Adaylarının Tasarladıkları Oyunların Türleri}

Katılımcı öğretmen adaylarının tasarladıkları oyunların türüne ilişkin veriler Şekil 3’te yer alan MAXQDA haritasında görülmektedir. 


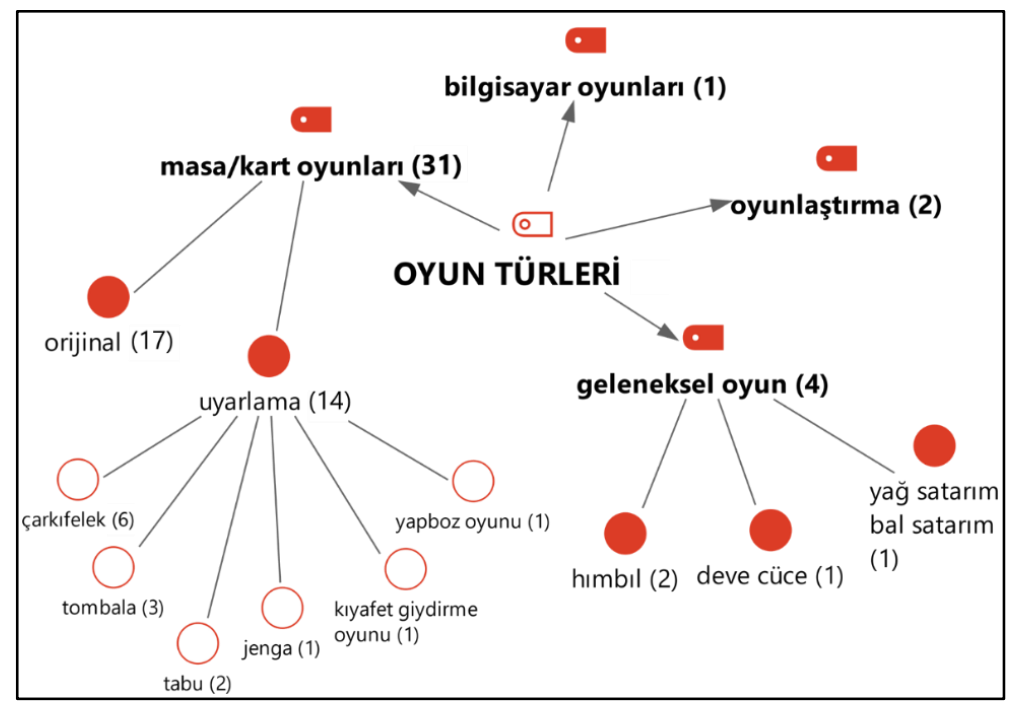

Şekil 3. Öğretmen Adaylarının Tasarladıkları Oyunların Türleri

Şekil 3'te görüldüğg̈ üzere matematik öğretmen adaylarının büyük çoğunluğu ( $f=31)$ derslerinde kullanmak üzere masa/kart oyunlarını tercih etmişlerdir. Bu oyunlardan bazıları bilinen masa/kart oyunlarının uyarlaması iken, bazıları ise orijinaldir. Aşağıda bu oyunlardan bazılarına ilişkin örnekler yer almaktadır.

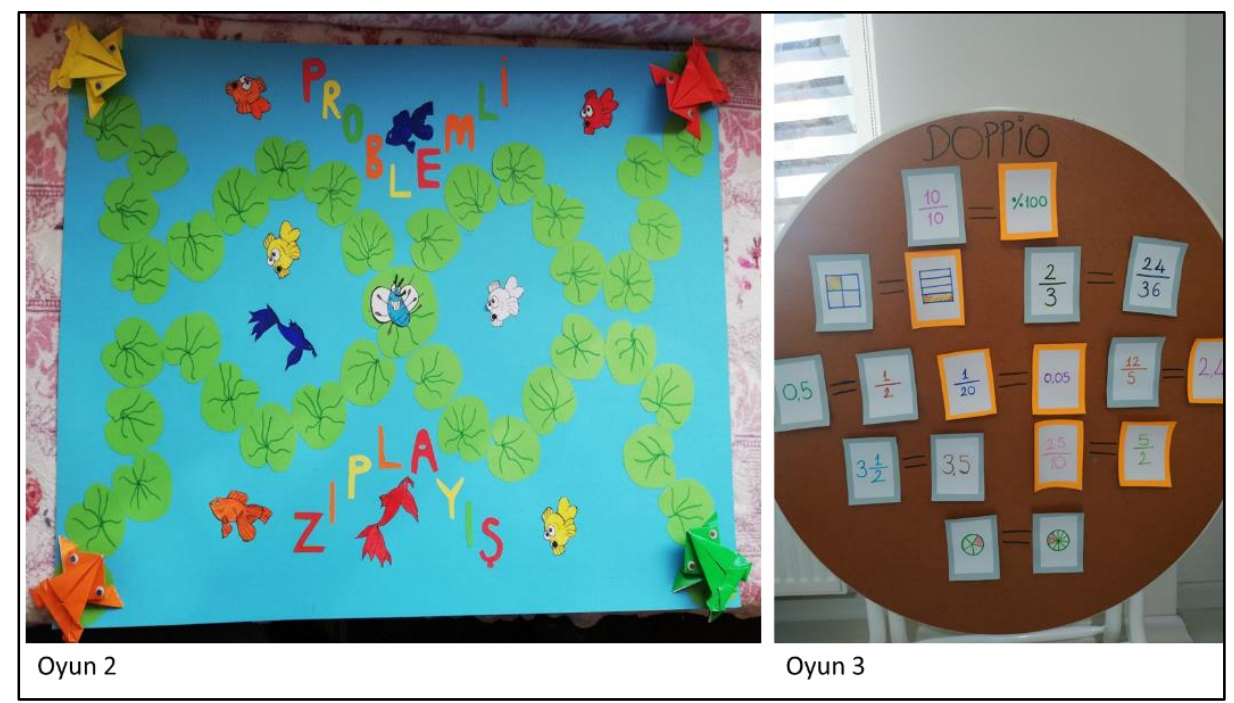

Şekil 4. Katılımcıların Tasarladıkları Orijinal Masa/Kart Oyunlarından Örnekler

Şekil 4'te yer alan oyunlardan ilki olan "Problemli Zıplayış" oyunu; 4 kişilik bir masa oyunudur ve 4 adet kurbağa piyonu bulunmaktadır. Bu oyunun kuralları sınıfta uygulanabilecek şekilde hazırlanmıştır. Sınıf dört takıma ayrılarak her takım bir kurbağayı temsil edecektir. Her kurbağaya ait 9 nilüfer yaprağından, sonu sineğe ulaşan yollar bulunmaktadır. "Doppio" ise hafıza oyunu mantığından yola çıkılarak oluşturulmuş, bir yüzeyde arka yüzü çevrili olarak duran kartları çiftler halinde ters çevirerek eşleşenleri bulmayı amaçlayan bir kart oyunudur.

17 öğretmen adayı ise bilinen masa/kart oyunlarını matematik dersine uyarlamayı tercih etmişlerdir. En çok uyarlanan oyun çarkıfelek olurken $(\mathrm{f}=6)$, tombala $(\mathrm{f}=3)$, tabu $(\mathrm{f}=2)$, jenga $(\mathrm{f}=1)$, kıyafet giydirme oyunu $(\mathrm{f}=1)$, yapboz oyunu da $(\mathrm{f}=1)$ diğer tercih edilen oyunlar arasındadır. Aşağıda Şekil 5 'te bu oyunlardan örnekler yer almaktadır. 


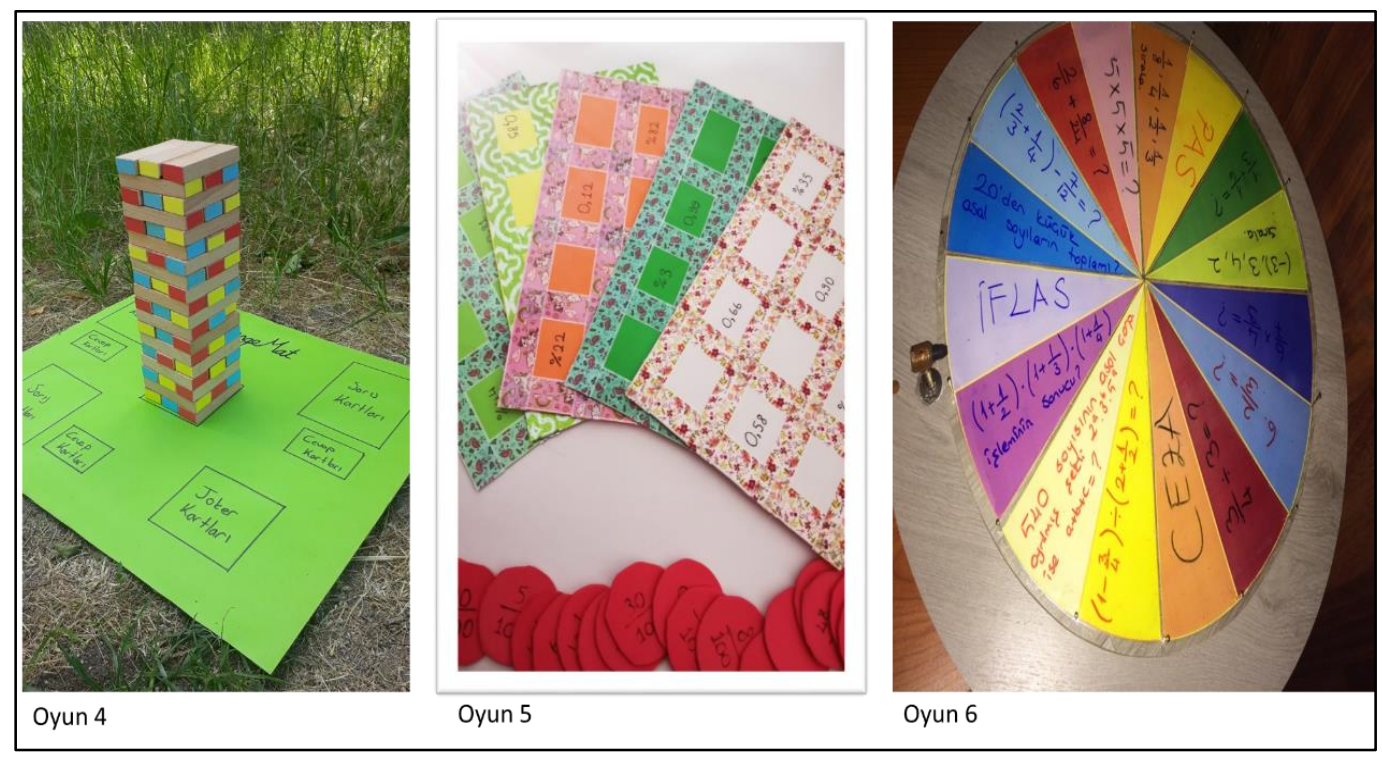

Şekil 5. Katılımcıların Tasarladıkları Uyarlama Masa/Kart Oyunlarından Örnekler

Yukarıda görülen Oyun 4 Jenga oyunundan uyarlanmış olup, adı "Dengemat"tır. 4 oyuncu için tasarlanmış olan bu oyunda üzerinde sarı, mavi, kırmızı dilimler olan bir çark bulunmaktadır. Çarkı çeviren oyuncu soruya doğru yanıt verdiğinde cevapladığı soru kartının renginde istediği bir DengeMat tahta bloğunu çeker ve çektiği bloğu en üste yerleştirir. Oyuncu soruya yanlış yanıt verdiğinde ya da süre bittiğinde verecek bir yanıtı olmadığında rakiplerinin fikir birliği ile söylediği DengeMat tahta bloğunu çeker ve çektiği bloğu en üste yerleştirir. DengeMat kulesini yıkan oyuncu oyunu kaybeder.

Oyun 5 ise "Tombmatik" isimli tombala oyunun bir versiyonudur. Bu oyun 5. sinif düzeyindeki ondalık gösterim ve yüzdelerle ilgili bazı kazanımların (M.5.1.5.2. Paydası 10, 100 veya 1000 olan bir kesri ondalık gösterim şeklinde ifade eder; M.5.1.5.4. Paydası 10, 100 veya 1000 olacak şekilde genişletilebilen veya sadeleştirilebilen kesirlerin ondalık gösterimine yazar ve okur; M.5.1.6.1. Paydas1 100 olan kesirleri yüzde sembolü (\%) ile gösterir; M.5.1.6.2. Bir yüzdelik ifadeyi aynı büyüklüğ̈̈ temsil eden kesir ve ondalık gösterimle ilişkilendirir, bu gösterimleri birbirine dönüştürür.) pekiştirilmesi amacıyla tasarlanmıştır. Oyunun içinde 10 tane oyun kartı bulunur. Sınıftaki öğrenci sayısı 11'e bölünür. Gruplardaki kişi sayısı yaklaşık 2-3 kişi olur. 10 tane gruba oyun kartları dağıtılır. Kalan grup ise öğretmen masasının üstünde içinde 120 tane kesir sayısı bulunan torbadan rastgele oyun pulu çeker ve çektikleri sayıy yüksek sesle kesirlerin okunuş kuralına göre okur. Kesirlerin okunuşunu yanlış yapan öğrenci torbayı diğer oyuncuya verir. Oyun kartı bulunan öğrenciler ise, kartların üstünde bulunan yüzdelik ve ondalık gösterimi verilen sayıları kesir haline dönüştürür ve eğer gerekiyorsa o kesri sadeleştirip genişleterek, arkadaşların okuduğu sayılardan hangisine karşılık geliyorsa o oyun pulunu alır ve kartının üstünde bulunan ondalık veya yüzdelik sayıyı kapatır. Bütün sayıları kapatan grup oyunu kazanır ve öğretmen masasında sayıyı okuyan grupla yer değiştirir.

Bir diğer oyun olan "Çevir Çöz” (Oyun 6) 6. sınıf Sayılar ve İşlemler öğrenme alanının birden fazla kazanımının pekiştirilmesi amacıyla hazırlanmış, bir nevi genel tekrar işlevi görmektedir. Bu oyunda sınıf mavi, yeşil ve kırmızı olmak üzere üç gruba ayrılır. Mavi gruptan başlayarak bir kişi gelir ve çarkı çevirir. Eğer üstünde soru yazan bölüm denk geldiyse soruyu çözer. Her doğru çözülen soru için takım 100 kazanır. Yanlış çözülürse takımdan 50 puan eksilir. Eğer çarkı çevirdiğinde "PAS" gelirse puan yükleme olmadan diğer gruba geçer. Çark çevrildiğinde "IFLAS" bölmesi gelirse takımın sahip olduğu puan sıfirlanır. Çark çevrildiğinde "CEZA" kısmına gelirse eğer ceza kartlarından birer kart seçilerek o cezalar yerine getirilir. 
Dört öğretmen adayı ise masa/kart oyunu yerine geleneksel bir oyunu matematik öğretimine uyarlamışlardır. Oyun tasarımları için bir öğretmen adayı "Yağ Satarım Bal Satarım", 1 öğretmen adayı "Deve Cüce" oyununu tercih ederken, 2 öğretmen adayı da "Hımbıl" oyununu uygun gördükleri matematik kazanımlarına uyarlamayı tercih etmişlerdir. Bu öğretmen adaylarından biri "Ondalıkl Hımbıl" ismini verdiği oyunda Hımbıl oyununu "M.6.1.6.2. Ondalık gösterimleri verilen sayıları çözümler." kazanımının öğretiminin ardından pekiştirme amacıyla uyarlamıştır (Şekil 6).

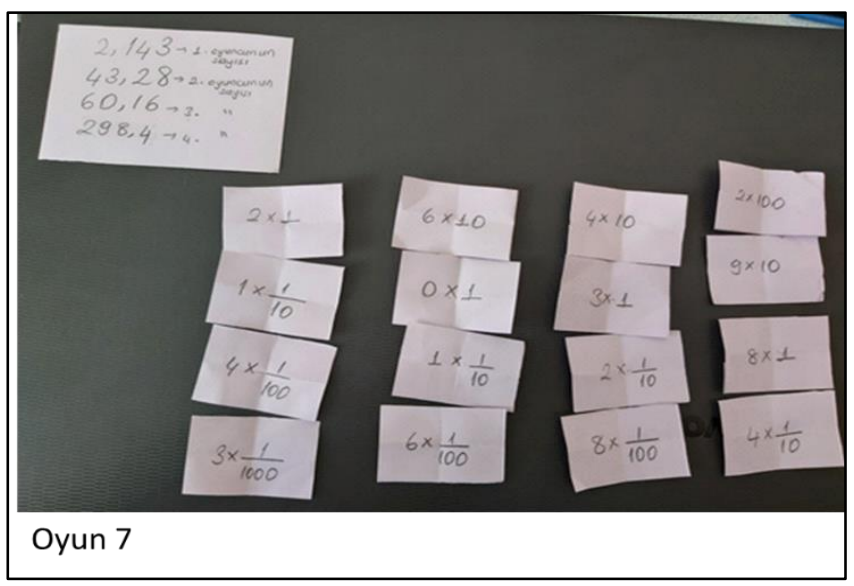
Örnek

Şekil 6. Geleneksel Oyunumuz Hımbıl'’n Matematik Dersine Uyarlanmış Biçimine Bir

Yukarıda görseli verilen "Ondalıklı Hımbıl" oyununa başlamadan önce gruplar oluşturulur. Oyuncular kendilerine gruptaki kişi sayısı kadar basamak içeren bir ondalık kesir sayısı seçerler ve bu sayının çözümlenmiş halini parça kağıtlara ayrı ayrı birer defa yazar. Bu aşamada öğrencilerin çözümlemeleri doğru yaptığından emin olmak için, öğretmen kontrol etmelidir. Her oyuncu kendi yazdığ 1 kağıtları içindeki yazılar görünmeyecek şekilde katlar. Oyunculardan birisi kartları elinde karıştırır ve ortaya döker. Her bir oyuncu ortada katlanmış olan kağıtlardan kişi sayısı kadar kağıt alır. Kağıtları açar ve çözümlenmiş haldeki sayıları yan yana koyarak bir ondalık sayı oluşturmaya çalışır. Eğer elinde aynı basamağı oluşturan ifadelere ait birden fazla kağıt varsa fazlalığı yanındakine verir. Her bir oyuncu bu şekilde oyunu ilerletir.

Bir öğretmen adayı da 7. sınıf öğrencilerine cebirsel ifadeler konusunu pekiştirmek için Scratch programında aşağıda görseli verilen "Cebirsel ifadeler Topla" ve "Kartları Bil Senin Olsun" oyunlarını tasarlamıştır.

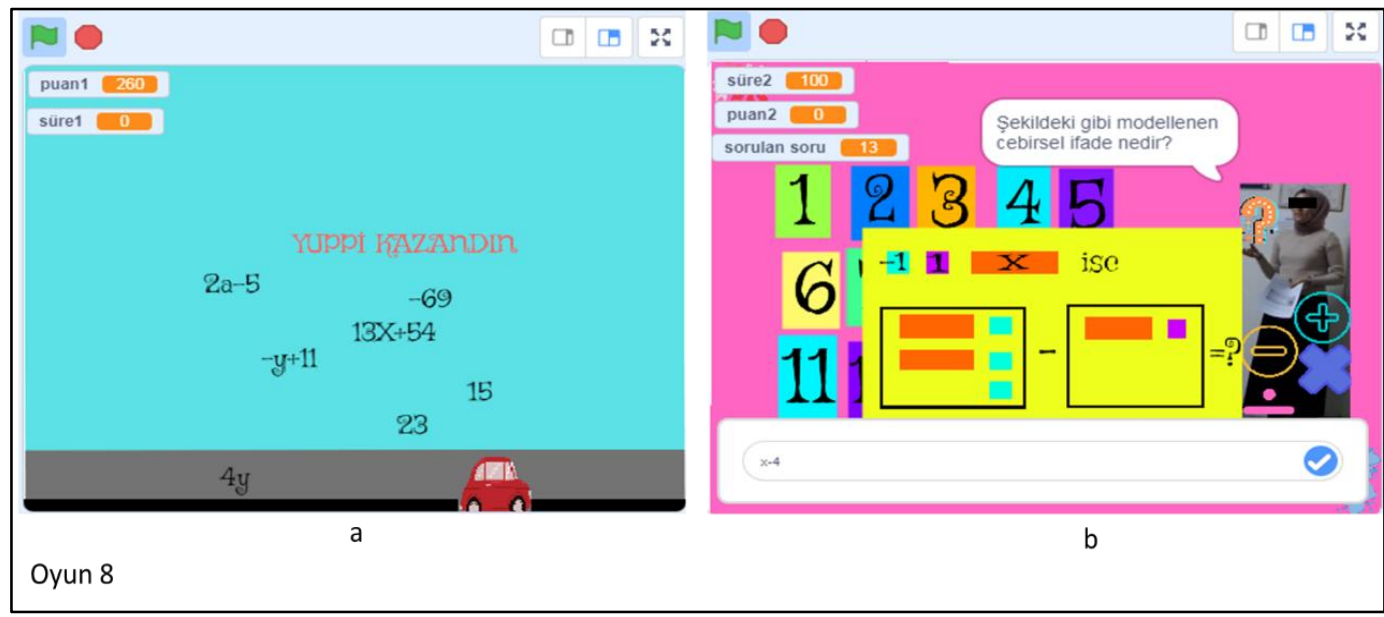

Şekil 7. Cebirsel İfadeler Konusunu Pekiştirmek İçin Bir Öğretmen Adayı Tarafından Geliştirilmiş Bilgisayar Oyunu 
Bilgisayar laboratuvarında tüm sınıfla oynanması hedeflenen "Cebirsel ifadeler Topla" (Şekil 7a) oyununda arabayı sağ ve sol yön ok tuşları ile hareket ettirerek cebirsel ifade görüldüğünde yakalamak hedeflenmektedir. Cebirsel ifade yakalandığında 5 puan alınmakta, yakalanan ifade cebirsel ifade olmadığında ise 5 puan kaybedilmektedir.

“Kartları Bil Senin Olsun" oyununda (Şekil 7b) ise öğrenci sorulan soru tabelasından hangi sorunun sorulduğunu görüp, o soru kartını açacaktır. Bu sırada soruyu öğretmen diyalog balonunda soracaktır. Öğrenci cevabı ilgili alana yazıp, 'Enter' tuşuna veya cevap girdi alanının yanında bulunan 'tik' işaretine tıklayarak cevabını kontrol ettirecektir. Cevap doğru ise $(+5)$ puan, yanlışsa (-5) puan alacaktır.

İki öğretmen adayı da oyunlaştırma unsurlarından faydalanmayı tercih etmiştir. $\mathrm{Bu}$ öğretmen adaylarından biri "Çevir-Bil-Geç" ismini vermiş olduğu oyunu (Oyun 9) 7. sınıf Tam Sayılar alt öğrenme alanında yer alan kazanımların pekiştirilmesi amacıyla tasarlamıştır. Uygulama için haftanın 3 günü ders olduğunu varsayalım. Pazartesi, Salı ve Cuma günleri. Haftanın ilk dersi başlamadan önce öğrenciler sınıfın kapısında öğrenci yoklama listesi sırasına göre dizilir. Öğretmen gelip sırayla işlemiş olduğu konulardan karışık şekilde soru sorar. Bildikleri takdirde sınıfa girip istedikleri yere oturur ve bir sonraki hafta aynı güne kadar yeri matematik dersleri için belirlenmiş olur. Soruyu bilemediklerinde ise sıranın sonuna geçip tekrar soru sırasının kendilerine gelmesini beklerler. Sırada 5 kişi kalıncaya kadar soru sorup yanıt alma işlemi devam etmekte, son 5 kişi kaldığında ise çevir-bil-geç sona ermektedir. Soruların belirlenmesinde bir çark mekanizması kullanıldığı için oyuna "Çevir-Bil-Geç" ismi verilmiştir.

\section{3. Öğretmen Adaylarının Tasarladıkları Oyunların Sınıf Seviyeleri}

Katılımc öğretmen adaylarının tasarladıkları oyunların sınıf seviyelerine göre dağılımlarına ilişkin veriler Şekil 8'de yer alan MAXQDA haritasında görülmektedir.

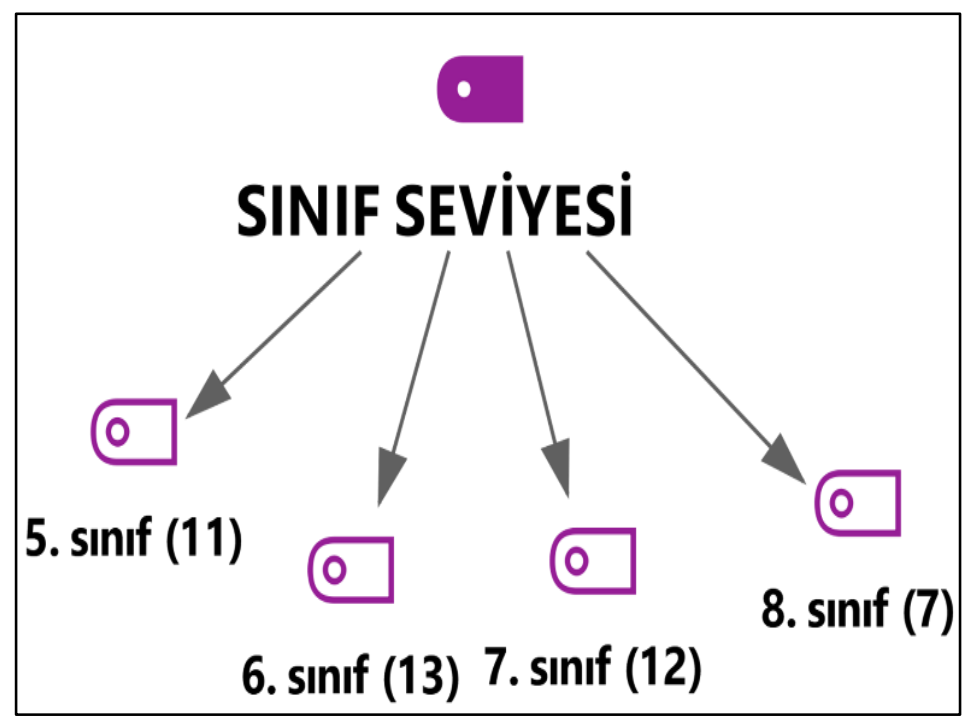

Şekil 8. Öğretmen Adaylarının Tasarladıkları Oyunların Sınıf Seviyelerine Göre Dağglımı

Şekil 8'de görüldüğü gibi öğretmen adayları matematik dersleri için tasarladıkları oyunları çoğunlukla 5. ( $\mathrm{f}=11), 6$. ( $\mathrm{f}=13)$ ve 7 . ( $\mathrm{f}=12)$ sınıf düzeylerine hitap edecek şekilde hazırlamışken, 8.sınıf $(\mathrm{f}=7)$ öğrencileri için oyun hazırlayan öğretmen adayı sayısı daha azdır. Öğretmen adaylarından bazıları oyunlarını sadece bir sınıf düzeyini baz alarak oluşturmamış, farklı sınıf seviyelerinde de kullanılabilecek oyunlar hazırlamışlardır. Bu yüzden frekansların toplamı 38 olmamaktadır. Bu öğretmen adaylarından biri aşağıda görseline yer verilen oyunu hem 7 , hem de 8 . sınıf öğrencilerinin oynayabileceği şekilde tasarlamıştır. 


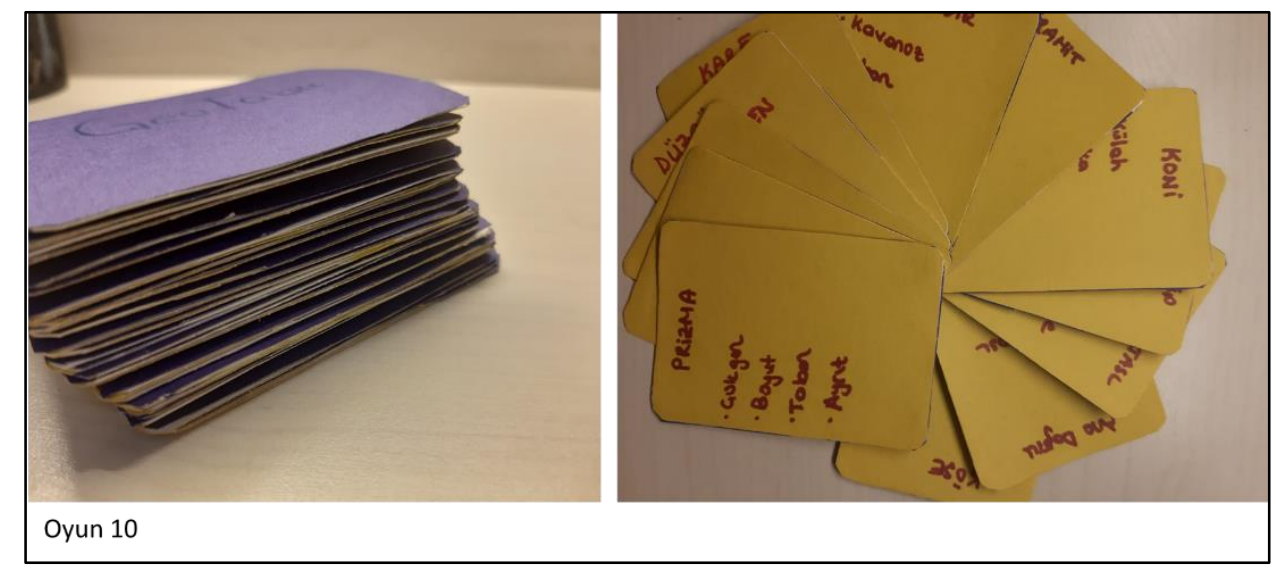

Şekil 9. İki Farklı Sınıf Düzeyi İçin Tasarlanmış Bir Oyun

Şekil 9'da tabu oyunundan uyarlanmış olan "Geotabu" isimli oyun 7 ve 8. sınıf Geometri ve Ölçme öğrenme alanının Çokgenler/Geometrik Cisimler alt öğrenme alanlarınında yer alan konuların pekiştirilmesi için hazırlanmıştır. Oyunda sınıfın iki gruba ayrılarak oynatılması hedeflenmiştir.

\section{4. Öğretmen Adaylarının Tasarladıkları Oyunların Öğrenme Alanları}

Öğretmen adaylarının matematik dersleri için tasarladıkları oyunların öğrenme alanları ve alt öğrenme alanlarına göre dağılımlarına ilişkin veriler Şekil 10'da yer alan MAXQDA haritasında görülmektedir.

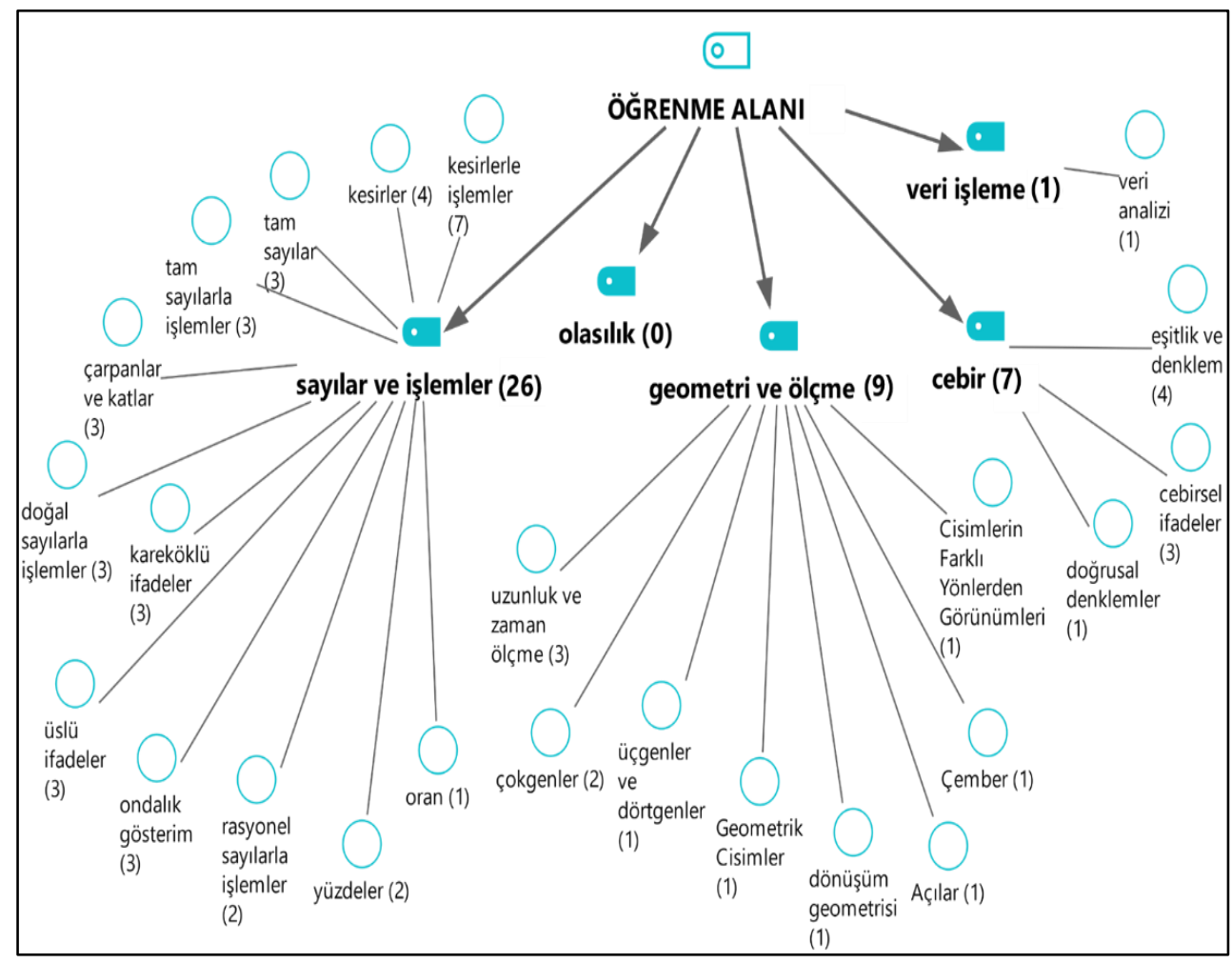
Dağılımı

Şekil 10. Öğretmen Adaylarının Tasarladıkları Oyunların Öğrenme Alanlarına Göre

Yukarıdaki şekilde (Şekil 10) görüldügü gibi en çok Sayılar ve İşlemler öğrenme alanına ( $\mathrm{f}=26)$ yönelik oyunlar tasarlanmışken, Geometri ve Ölçme $(\mathrm{f}=9)$, Cebir $(\mathrm{f}=7)$ ve Veri işleme $(\mathrm{f}=1)$ öğrenme alanlarına yönelik oyunlar da hazırlanmıştır. Ancak katılımcı matematik 
öğretmeni adaylarının Olasılık ( $\mathrm{f}=0)$ öğrenme alanına yönelik hiç oyun tasarlamamış oldukları görülmektedir. Öğrenme alanları ile alt öğrenme alanları arasındaki frekans farkı, bazı öğrencilerin oyunlarını tasarlarken, aynı öğrenme alanının farklı alt öğrenme alanlarına ait kazanımlarına yönelik de tasarım yapmalarından kaynaklanmaktadır.

Sayılar ve İşlemler öğrenme alanına yönelik hazırlanmış oyunlara bakıldığında ise daha çok "Kesirler" ( $\mathrm{f}=4)$ ve "Kesirlerde işlemler" ( $\mathrm{f}=7)$ alt öğrenme alanlarının tercih edildiği anlaşılmaktadır. Bir öğretmen adayı 5. sınıf düzeyinde "Sadeleştirme ve genişletmenin kesrin değerini değiştirmeyeceğini anlar ve bir kesre denk olan kesirler oluşturur." kazanımının konu anlatımı sonrasında pekiştirilmesi ve öğrencilerin konuyu daha iyi anlamaları amacıyla oynanabilecek iki aşamalı bir oyun tasarlamıştır. Bu oyuna ilişkin görsel Şekil 11'de yer almaktadır.

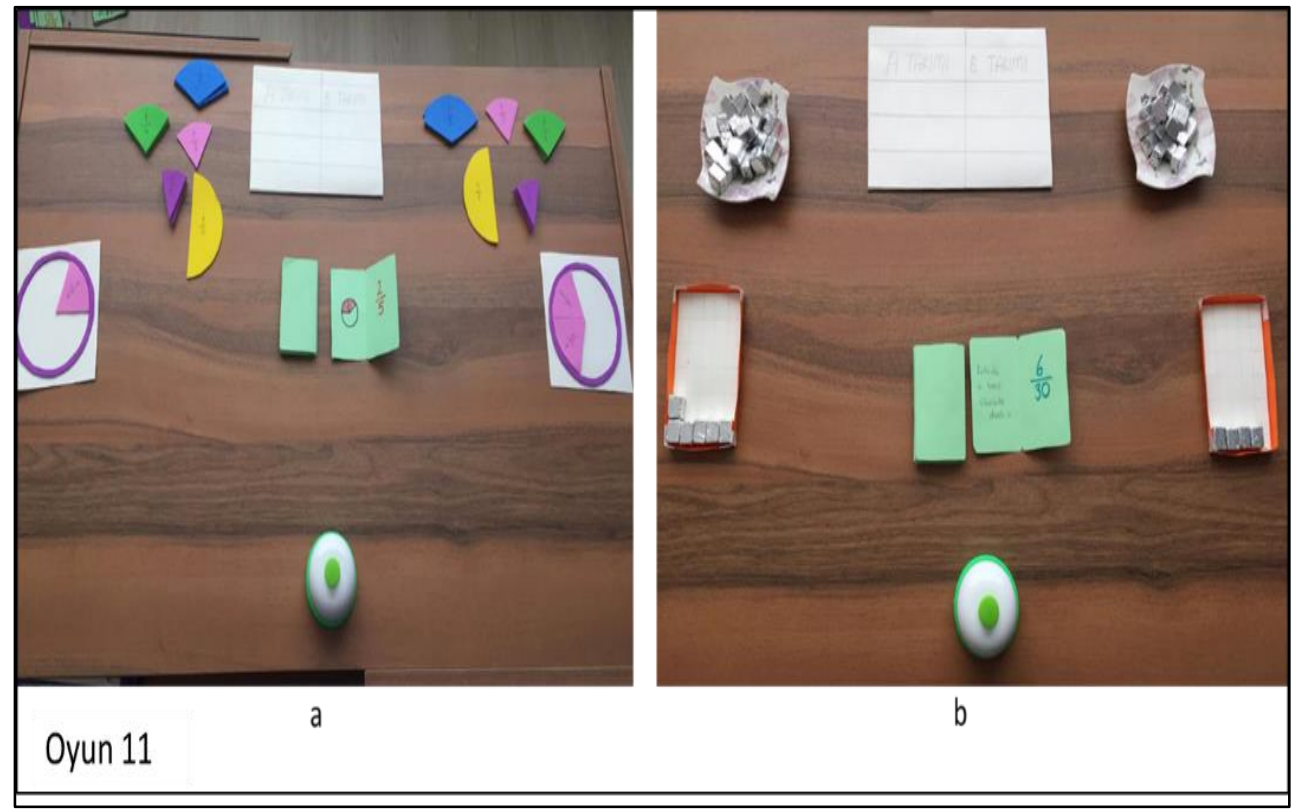
Örnek

Şekil 11. Sayılar ve İşlemler Öğrenme Alanınına Yönelik Hazırlanmış Oyunlardan Bir

Oyunda çözülmeye çalışılan problem soru kartlarındaki kesirleri istenilen duruma göre doğru bir şekilde hazırlamak ve hızlı olmaktır. "Ne kadar pizza yedim?" oyununda (Şekil 11a) oyuncular ortaya açılan kartta çıkan kesri en sade haline getirip, tabaklara pizza dilimlerini (birim kesirleri) kullanarak ifade etmeye çalışır ve hızlı bir şekilde zile basar. İkinci oyun yani "Ne kadar şeker yedim?" oyununda (Şekil 11b) oyuncular ortaya açılan kartta çıkan kesri kutunun kapasitesine göre genişleterek küp şekerleri (birim kesirleri) kullanarak ifade etmeye çalışır ve hızlı bir şekilde zile basar. Örneğin soru kartından $1 / 5$ çıksın. İki oyuncu kesri genişletip, birim kesirleri kullanarak kutuya yerleştirmeye çalışacaktır. 30 şekerlik bir kutu olduğuna göre, oyunculardan ilk önce 6 şekeri kutuya yerleştirip zile basan +4 puan alacaktır. Eğer kişi zile bastığı halde şekerleri yanlış dizmiş ise kendi puan hanesine -2 puan eklenecektir.

Geometri ve Ölçme öğrenme alanına yönelik tasarlanmış oyunlara bakıldığında ise uzunluk ve zaman ölçme $(\mathrm{f}=3)$, çokgenler $(\mathrm{f}=2)$, üçgenler ve dörtgenler $(\mathrm{f}=1)$, geometrik cisimler $(f=1)$, cisimlerin farklı yönlerden görünümü $(f=1)$, çember $(f=1)$, açılar $(f=1)$ ve dönüşüm geometrisi alt öğrenme alanları için hazırlanmış oldukları görülmektedir. $\mathrm{Bu}$ oyunlardan biri Şekil 12'de gösterilen Çokgenler alt öğrenme alanına yönelik tasarlanmış olan "Arı Maya'nın Çiçekleri" isimli oyundur. 


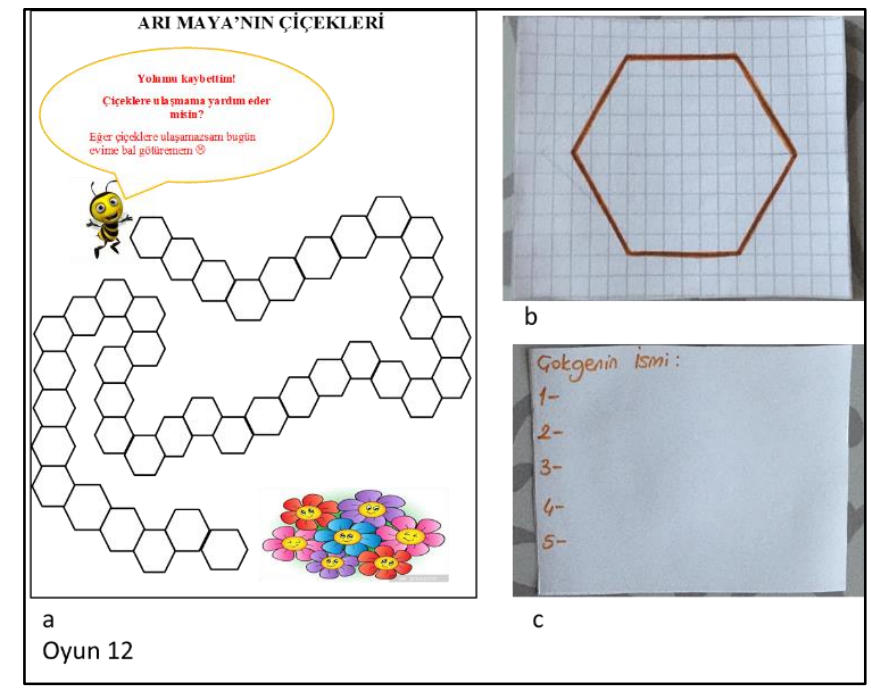
Örnek

Şekil 12. Geometri ve Ölçme Öğrenme Alanınına Yönelik Hazırlanmış Oyunlardan Bir

5. sınıflara yönelik Arı Maya'nın Çiçekleri isimli oyunda sınıf üç gruba ayrılır. Öğretmen her gruba bir renk ismi ve her grubun rengine uygun boyama kalemi (örneğin kırmızı gruba kırmızı renkte kuru boya) ile yukardaki Arı Maya'nın çiçeğe ulaşması için kullandığı yol çıtısını verir. Öğretmen her gruba 5 dakika verip çektikleri karttaki çokgenin ismini ve özelliklerini bulmasını ve çokgen kartının arkasına yazmasını ister. Arı Maya'nın çiçeklere ilk ulaşmasını sağlayan grup oyunu kazanacaktır.

7 öğretmen adayı ise cebir öğrenme alanına göre oyun hazırlamayı tercih etmişlerdir. $\mathrm{Bu}$ öğretmen adayları daha çok eşitlik ve denklem $(\mathrm{f}=4)$ alt öğrenme alanını tercih etmişlerdir. Cebirsel ifadeler $(\mathrm{f}=3)$ ve doğrusal denklemler $(\mathrm{f}=1)$ alt öğrenme alanlarının pekiştirilmesi amacıyla hazırlanan oyunlar da bulunmaktadır. Cebir öğrenme alanında yer alan kazanımlardan "Birinci dereceden bir bilinmeyenli denklemi tanır ve verilen gerçek hayat durumlarına uygun birinci dereceden bir bilinmeyenli denklem kurar" ve "Birinci dereceden bir bilinmeyenli denklemleri çözer" kazanımlarına yönelik hazırlanan "Eşle Denklemi Çöz Problemi" oyununa ilişkin görsel Şekil 13'te yer almaktadır.

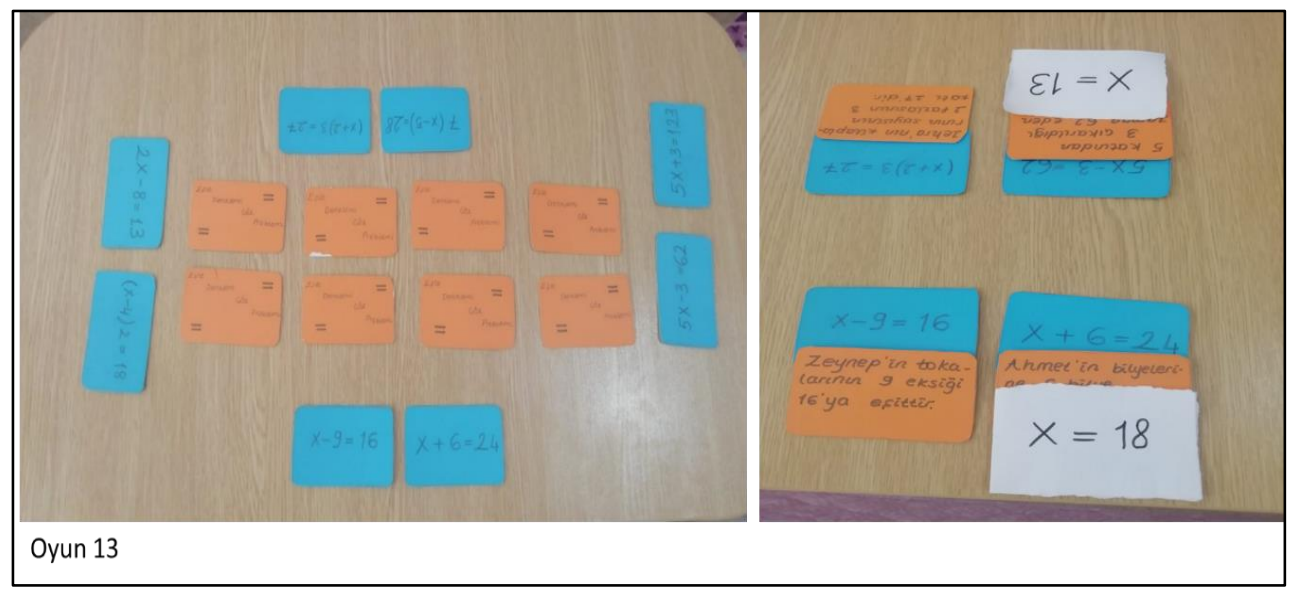

Şekil 13. Cebir Öğrenme Alanınına Yönelik Hazırlanmış Oyunlardan Bir Örnek

"Eşle Denklemi Çöz Problemi” (Oyun 13) oyunu oyun kartlarının birbiri ile eşleştirilmesi esasına dayanmaktadır. $\mathrm{Bu}$ kartlardan turuncu olanlarda denklemlerle ilgili sözel ifadeler yazılıdır. Mavi kartlarda ise cebirsel olarak denklem ifadeleri yazılıdır. Oyunda amaç turuncu kartlardaki sözel ifadeleri öğrencilerin ellerindeki denklemlerle uygun şekilde eşleştirmektir. 
Mavi kartların üzerini ilk kapatan iki kişi oyunun diğer aşaması olan denklem çözme kısmına geçecektir. Öğrencilerden her biri denklemlerini yanlışsız olarak çözmeye çalışacaklardır. Denklemlerini ilk ve doğru çözen oyunu kazanacaktır.

Olasılık öğrenme alanına ilişkin hiç oyun tasarlanmamışken, veri işleme öğrenme alanına ilişkin "MAVO (Matematiksel Veri Oyunu)" adında bir oyun hazırlanmıştır. Bu oyunda öğrencilerden Şekil 14'te görülen dönen çarkta alta düşecek topun rengine göre öğretmenin vermiş olduğu veriler ışığında grubu ile birlikte grafik çizmesi ve medyan, aritmetik ortalama ve mod değerlerinden alta düşen topun rengine karşılık gelen değeri bulması istenir.

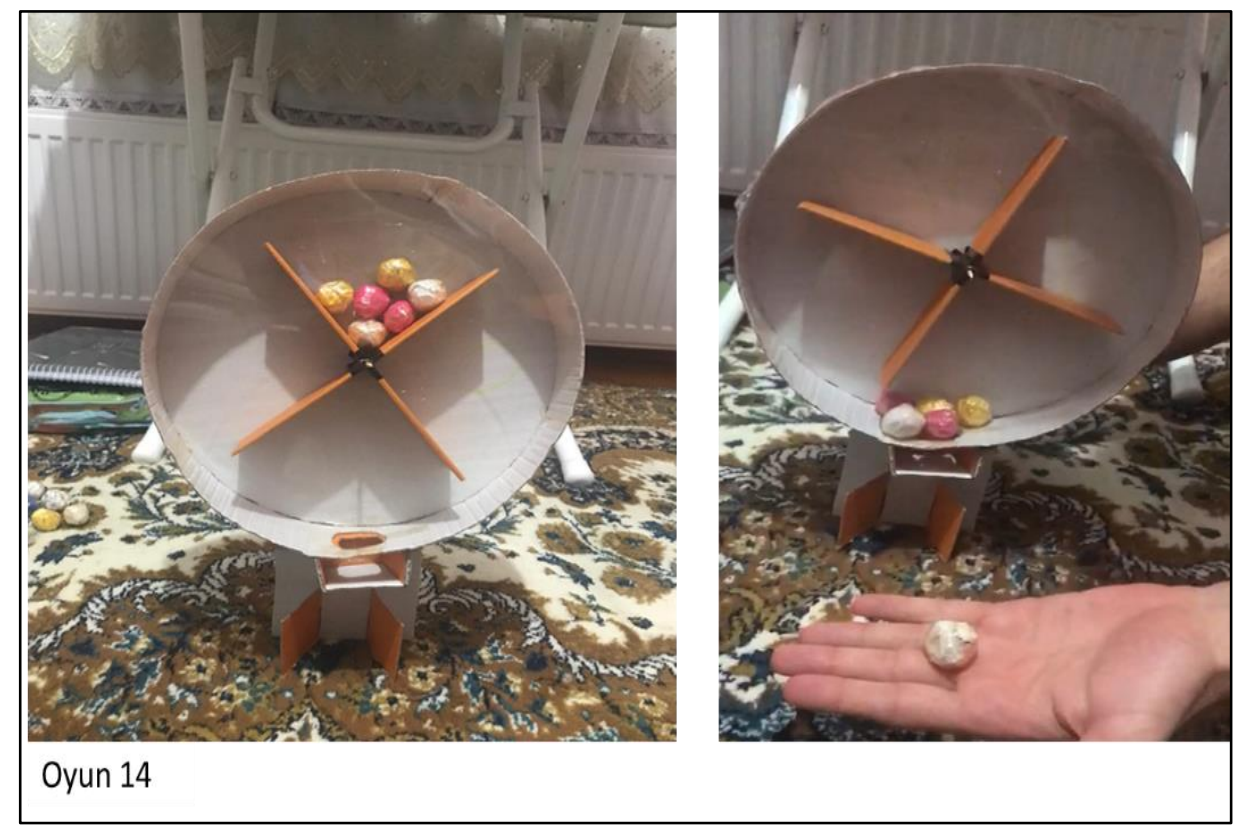

Şekil 14. Veri İşleme Öğrenme Alanına Yönelik Hazırlanmış Oyunlardan Bir Örnek

Şekil 14'te görseline yer verilen " $M A V O$ " oyununda her grup bu işlemi üç defa tekrarlar ve en çok doğru cevabı veren grup kazanmış sayılır. Toplarının renklerinin anlamı şu şekildedir: "1. çevirme için sarı- sütun grafiği, beyaz- çizgi grafiği ve pembe- daire grafiğgi; 2. çevirme için sar1- mod, beyaz- medyan ve pembe- aritmetik ortalama".

\section{5. Öğretmen Adaylarının Tasarladıkları Oyunların Oyuncu Sayısı}

Ortaokul matematik öğretmeni adaylarının hazırladıkları oyunların kaç kişi ile oynandığına ilişkin veriler Şekil 15'te yer alan MAXQDA haritasında görülmektedir.

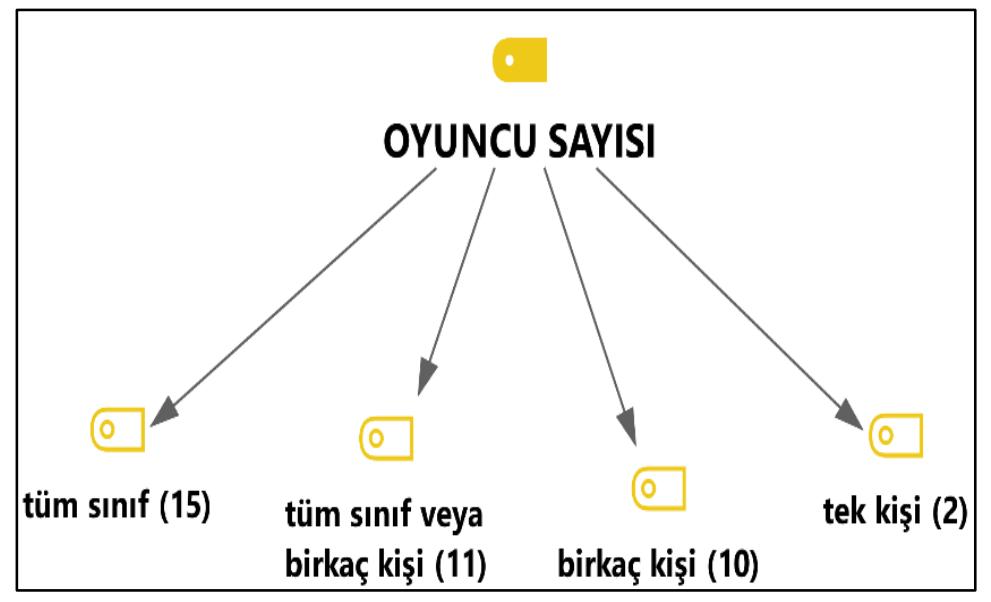

Şekil 15. Öğretmen Adaylarının Tasarlamış Oldukları Oyunların Oyuncu Sayısı 
Şekil 15'te görüldüğü gibi 38 matematik öğretmeni adayından 15 'i oyunlarını sınıftaki tüm öğrencilerin katılımını sağlayabilecek şekilde hazırlamışken, 11 kişi hem birkaç öğrenci hem de tüm sınıfın katılım sağlayabileceği oyunlar hazırlamışlardır. 2 öğretmen adayı sadece tek kişinin oynayabileceği bir masa/kart oyunu tasarlamışken, 10 öğretmen aday1 da 2-6 kişinin oynayabileceği oyunlar tasarlamışlardır. Hem sınıf ortamında tüm öğrencilerin katılımıyla hem de iki kişi ile oynanan bir oyun örneğinin görseline Şekil 16a'da, bir kişilik bir oyun örneğinin görseline de Şekil 16b'de yer verilmiştir.

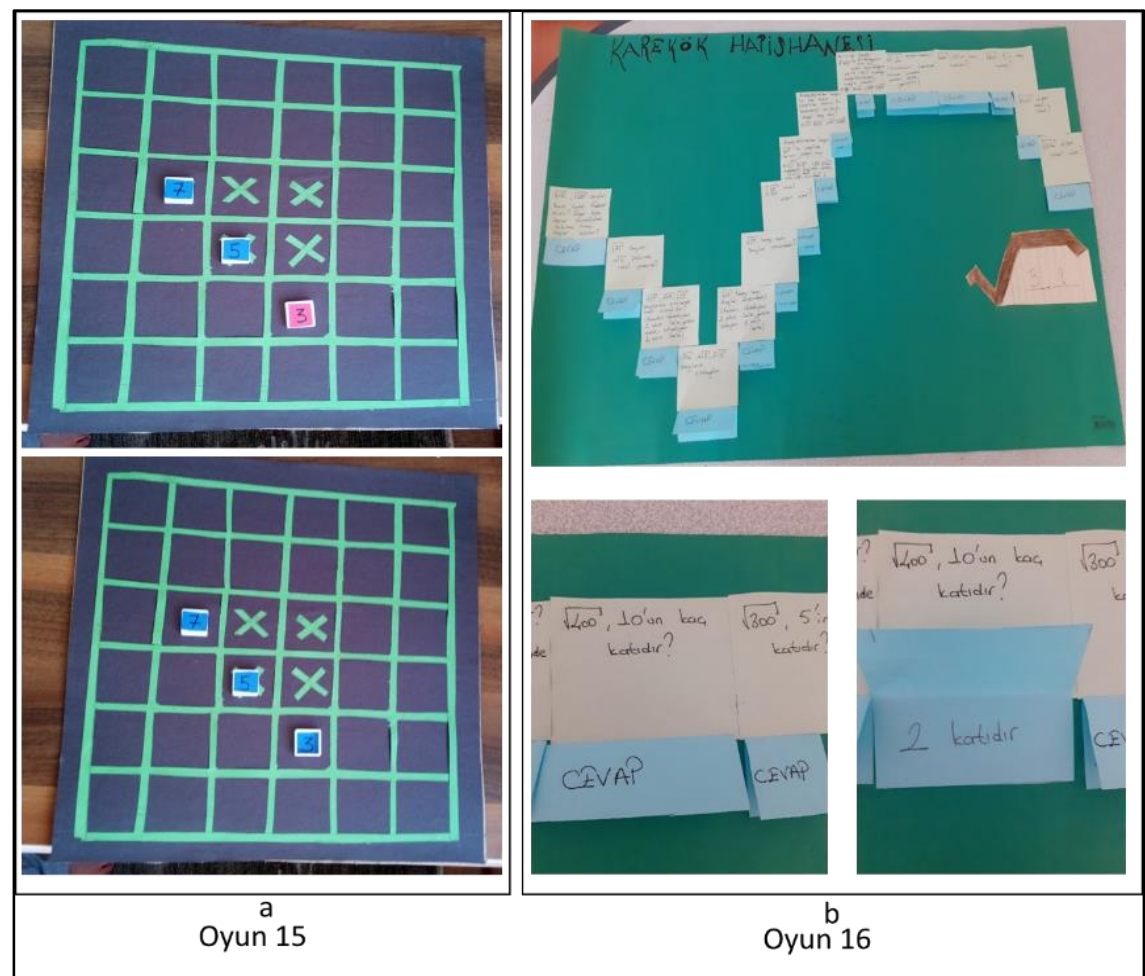

Şekil 16. Tüm Sınıfın veya Birkaç Kişinin Oynayabileceği Ve Tek Kişinin Oynayacağı Birer Oyun Örneği

Şekil 16a'da yer alan Oyun 15 "Böl-Çevir" oyunudur. Bu oyun 6. sınıf Çarpanlar ve Katlar alt öğrenme alanının pekiştirilmesine yönelik bir oyundur. İlk olarak oyuna kimin başlayacağını belirlemek için havaya bir taş atılır. Taş mavi gelirse mavi, taş pembe gelirse pembe oyuna başlar. İlk olarak her oyuncu istediği iki taşı $\mathrm{x}$ işaretli yere çapraz şekilde koyar. Art arda üç taşın toplamının belirlenen bölünebilme kuralını sağlamasıdır. Oyunun en can alıcı kısmı ise aynı renkten iki taşın ve farklı renkli taşın toplamı eğer belirlenen bölünebilme kuralını sağlıyorsa farklı renkli taş ters çevrilip tüm taşların aynı olmasını sağlar. Oyunun bitmesi için zemindeki her kutucuğun dolu olması gerekir.Ya da oyunculardan herhangi birinin hamle yapamaması gerekir.Yani herhangi bir hamlenin belirlenen bölünebilme kuralına tam bölünememesi gerekir. Bu oyun iki kişi ile oynanabileceği gibi, renkli kâğıtlarla ve deftere 6'ya 6 lık bir zemin hazırlayarak oyun çoğaltılabilir ve tüm sınıfla bu oyunun turnuvası yapılabilir.

Şekil 16b'de yer alan Oyun 16 (Karekök Hapishanesinden Kurtuluş) ise aslında birden fazla kişi ile oynanabilecek şekilde uyarlanabilecek olsa da, oyunu tasarlayan öğretmen adayı bu oyunun yalnızca tek kişi ile oynanabilen bir oyun olduğunu belirtmiş̧ir. Oyunda kareköklü sayılar ile ilgili işlemleri gerçekleştirerek şekil üzerinde ilerleyip sonuca ulaşma söz konusudur.

\section{6. Öğretmen Adaylarının Tasarladıkları Oyunların Oynanacağı Yerler}

Şekil 17'de yer alan MAXQDA haritasında öğretmen adaylarının tasarladıkları oyunların nerede oynanacağına ilişkin veriler görülmektedir. 


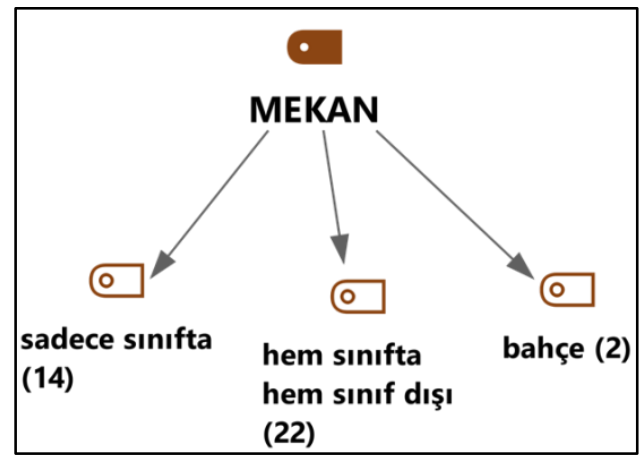

Şekil 17. Öğretmen Adaylarının Tasarlamış Oldukları Oyunların Oynanacakları Yerler

14 matematik öğretmeni adayı oyunlarını sadece sınıf ortamı için tasarlamışken, 22 oyunun hem sınıfta hem de sınıf dışında oynanabilecek şekilde tasarlandığı görülmektedir. 2 öğretmen adayı ise okul bahçesinde oynanabilecek oyunlar tasarlamıştır. Oyun 1 sadece sınıf ortamında oynanabilecek bir oyunken; Oyun 12, Oyun 15 hem sınıfı gruplara bölerek sinıf ortamında, ya da birkaç kişiyle sınıf dışında oynanabilecek oyunlardır. Şekil 18'de görseline yer verilen Oyun 17 ise bahçede oynamak için tasarlanmış bir oyundur.

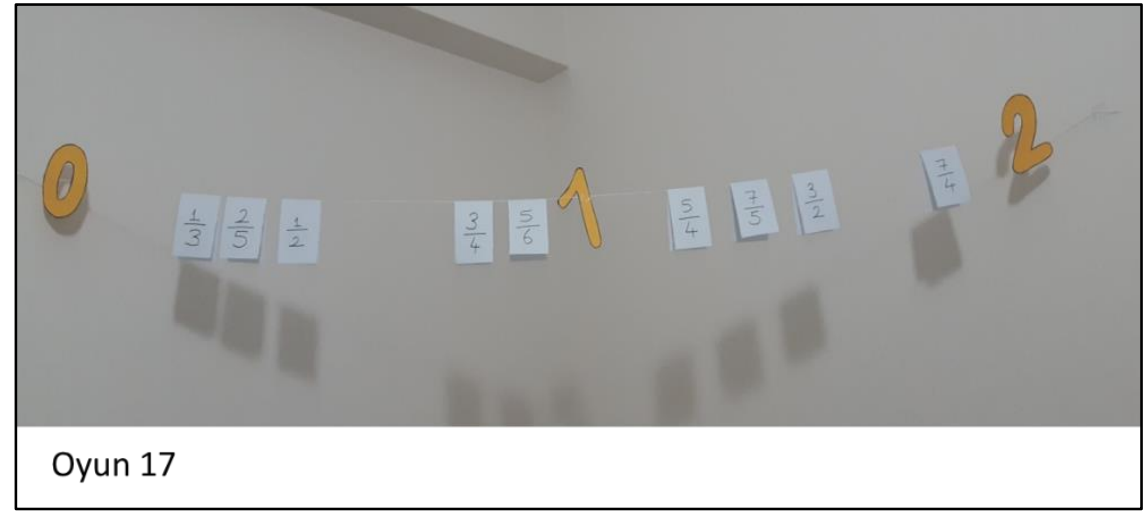

Şekil 18. Okul Bahçesinde Oynanan Oyunlardan Biri

"İpe Kesir Serme" oyunu (Oyun 17) "Kesirleri karşılaştırır, sıralar ve sayı doğrusunda gösterir" kazanımının pekiştirilmesi amacıyla hazırlanmıştır. Okul bahçesinde sınıf iki gruba bölünerek oynanan bu oyunda, iki grup da kendi ipleriyle aralarında 3 metre civarı uzaklık bırakarak tek sıra halinde dizilir. Bir tur için öğretmen 2 dakika süre tutar. Öğrenciler bu süre içerisinde torbalarındaki kesirlerin hepsini sayı doğrusunda uygun yerlere yerleştirmeye çalışırlar (denk kesirler olursa bu kâğgtlar üst üste yerleştirilir). Bunun için süre başlar başlamaz iki tekli sıranın da en başındaki iki ögrenci torbadan kesir alıp ipe koşmaya başlar. O kişi kesrini yerleştirip sıranın en arkasına geçtiğinde sıra en öndeki öğrenciye geçer ve en öndeki öğrenci koşmaya başlar. İki dakika boyunca bu durum böyle devam eder. Bu süre içinde iki grup da kesirlerini bitirdiğinde öğretmen iki grubun da sayı doğrusunu kontrol eder. Sayı doğrusu doğru olan grup 1 puan alır. Sıralamasında yanlışlık olan veya eksik kesri olan grup puan alamaz. Ancak öğretmen yine de sayı doğrularını kontrol eder ve yanlış varsa söyler.

\section{TARTIŞMA, SONUÇ VE ÖNERILER}

$\mathrm{Bu}$ çalışma ortaokul matematik öğretmeni adaylarının öğretmen olduklarında matematik derslerinde kullanmak amacıyla tasarlamış oldukları oyunları farklı açılardan ele almaktadır. Çalışmadan elde edilen bulgular öğretmen adaylarının \%80'ninden fazlasının tasarımlarında masa/kart oyunlarını tercih ettiklerini göstermektedir. Dolayısıyla katılımcılar çoğunlukla karton, mukavva vb. kolay erişilebilen malzemelerle bir oyun tablası hazırlayarak, tüm sınıf, 
birkaç kişi veya tek kişiye yönelik oyunlar tasarlamışlardır. Masa/kart oyunlarının oyun ve öğretimin bütünleştiği ve farklı yöntemlerin bir araya geldiği bir öğretim ortamına katkıda bulunduğu (Bayram, 2015) göz önüne alınırsa, bu durumun olumlu olduğu söylenebilir. Kaldı ki Jimenez Silva, White Taylor ve Gomez'e (2010) göre öğrenciler masa oyunlarını kullanarak matematiğin günlük yaşamlarında nasıl uygulanabilir ve değerli olduğunu görebilirler. Gobet, de Voogt ve Retschitzki (2004) ise iyi belirlenmiş kuralları nedeniyle masa oyunlarının tercih edildiğini ileri sürmektedir. $\mathrm{Bu}$ açıdan bakıldığında bir oyun tahtası üzerinde gerçekleştirildikleri için daha net sınırları olan masa oyunlarının öğretmen adayları tarafından daha fazla tercih edilmiş olduğu düşünülmektedir. Masa/kart oyunlarını tercih eden matematik öğretmeni adaylarının bir kısmı herkes tarafından bilinen ve sevilen oyunları matematik dersine uyarlamayı tercih ederken, bir kısmı da seçtiği konuya uygun orijinal bir oyun tasarlama yoluna gitmiştir. Uyarlama yapmayı tercih eden öğretmenler tarafından en çok çarkıfelek oyunu tercih edilmiştir. Bilindiği üzere ülkemizde 1970'li y1llardan günümüze birçok kez televizyon ekranlarında gördüğümüz "Çarkıfelek", ödül, dönüt gibi oyun unsurlarını barındırması, birçok konu ve duruma uyarlanarak bir yarışma ortamı oluşturabilmesi sebebiyle öğretmen adayları tarafından tercih edilmiş olabilir. Çarkıfelek dışında tombala, tabu, jenga, kıyafet giydirme ve yapboz oyunu da uyarlama yapmak için tercih edilen diğer oyunlar olmuştur.

Araştırmalar geleneksel oyunların matematik öğretiminde kullanılmasının olumlu sonuçlar vereceği üzerinde durmaktadır (Hacısalihoğlu Karadeniz, 2017; Risdiyanti, Prahmana ve Shahrill, 2019). Öğrencilere kültürel mirasın aktarılması ve matematiğin eğlenerek öğrenebilmesine yardımcı olacağı düşünülen geleneksel oyunların (Hacısalihoğlu Karadeniz, 2017) eldeki araştırmada da birkaç öğretmen adayı tarafindan tercih edildiği görülmüştür. Hımbıl, Deve-Cüce ve Yağ Satarım Bal Satarım oyunları matematik öğretim programında yer alan farklı kazanımlara uyarlanarak, pekiştirme amaçlı kullanımı hedeflenmiştir. Geleneksel oyunların daha az tercih edilmesinin sebebi, öğrencilerin 2000'li yıllarda doğmuş olmaları ile ilişkilendirilebilir. Çünkü bu yıllarda artık çocuklar sokakta, parkta vs. arkadaşları ile oynamak yerine; teknolojik araçlarla, bireysel ve kapalı ortamlarda oyun oynamayı tercih etmektedir (Horzum, 2011).

Günümüzde çocukların zamanlarının çoğunu bilgisayar oyunu oynayarak geçirdiğini (Akın ve Atıcı, 2015; Kafai, 2001) ve bilgisayar oyunlarının matematik ögretiminde olumlu sonuçlar verdiğini ortaya koyan araştırmalara (Abrams, 2008, Fırat, 2011; Tüzün, Arkun, Bayırtepe Yağız, Kurt ve Yermeydan Uğur, 2008) rağmen, sadece bir öğretmen aday1 matematik dersinde kullanılmak üzere bilgisayar oyunu geliştirmiştir. Bilindiği üzere her ne kadar bilgisayar oyunu oynayabilmek için derin bilgisayar bilgisine sahip olmak gerekmese de (Donmuş, 2012), bilgisayar oyunu tasarlayabilmek için belli seviyede bilgisayar bilgisine sahip olunması gerekmektedir. Öğretmen adaylarının bu sebepten ötürü bilgisayar oyunu tasarlamaktan kaçındığı düşünülebilir. İki öğretmen adayı ise dersleri için bir oyun tasarlamak yerine derslerinde oyunlaştırma unsurlarına yer verecekleri taslak bir ders planı oluşturma yolunu seçmişlerdir.

Ortaokul matematik öğretmenlerinin geliştirmiş oldukları oyunları ele alan bu çalışmada, 5, 6 ve 7. sınıfa yönelik daha fazla oyun geliştirilmişken, 8. sınıfa yönelik daha az oyun tasarlanmış olması dikkat çekicidir. Öğretmen adayları 8. sınıf öğrencilerinin sınava hazırlık aşamasında oldukları için derslerinde oyunlara yer vermekten kaçınmış olabilirler. Kinchin de (2018) sinavlar söz konusu olduğunda ciddi olmak ve öğrenmeye odaklanmak gerektiği şeklinde bir alg1 olduğunu öne sürmektedir. Oysaki ilköğretim, ortaöğretim hatta üniversite müfredatlarında bile yer alan matematik konularının öğretiminde oyunlardan yararlanılabileceği (Uğurel ve Moralı, 2008) bilinmektedir. Ayrıca eğlenirken ve oyun oynarken öğrenmenin, oturup öğrenmeye konsantre olmaktan çok daha kolay olduğu bilinmektedir (Kinchin, 2018).

Her ne kadar her matematik konusunun öğretiminde oyunlardan faydalanmak mümkün olsa da bu araştırmaya katılan matematik öğretmeni adayları oyun tasarlarken en çok "Sayılar ve İşlemler" alt öğrenme alanını tercih etmişlerdir. Sayılar ve İşlemler öğrenme alanında ise 
kesirlerle işlemler ve kesirler alt öğrenme alanlarına daha fazla yönelmişlerdir. Kesirlerin gerek öğretmenler gerekse öğrenciler için en zor görülen konulardan biri olarak görülmesi (Gürbüz, Gülburnu ve Şahin, 2017), öğretmen adaylarında bu konunun öğretimini eğlenceli hale getirme arzusu uyandırmış olabilir. Kaldı ki kesirlerin öğretiminde oyunların etkili olduğunu ortaya koyan çalışmalar da mevcuttur (Aksoy ve Kaleli Yılmaz, 2011; Gökbulut ve Yücel Yumuşak, 2014; Gürbüz, Gülburnu ve Şahin, 2017; Tucker, 2014).

$\mathrm{Bu}$ araştırma kapsamında oyun tasarlayan öğretmen adaylarının Sayılar ve İşlemler öğrenme alanındaki kadar olmasa da, Geometri ve Ölçme ve Cebir öğrenme alanlarında da oyunlar tasarladıkları görülmüştür. Sayılar ve İşlemler ile Geometri ve Ölçme öğrenme alanlarına yönelik diğer öğrenme alanlarına göre daha fazla oyun tasarlanmış olmasının sebebi, öğretim programında da bu alanların diğerlerine göre kazanım sayısı açısından daha yoğun olması olabilir. Ancak araştırma kapsamında Veri İşleme öğrenme alanında yalnızca bir tane oyun tasarlanmışken, Olasılık öğrenme alanında ise hiç oyun tasarlanmamış olması da ilgi çekicidir. Oysa zarlar, torbanın içinde farklı renkte toplar gibi farklı oyunlarda yer alan materyallere olasılık problemlerinde sıklıkla yer verilmektedir. Pratt (2000) de olasılik kavramını anlamlandırmak için, çeşitli manipülatiflerden, zarlardan, kartlardan, bilgisayar simülasyonlarından yararlanmanın etkili olduğunu dile getirmiştir. Olasılık alanına ilişkin ilköğretim matematik öğretmenliği bölümü öğrencilerinin hiç oyun tasarlamamış olmaları, bu alanda alan bilgilerinin daha düşük düzeyde olmasından da kaynaklanıyor olabilir. Kaldı ki Ata (2013) olasılık konusunda özellikle kavramsal bilgi bağlamında ilköğretim matematik öğretmeni adaylarının yetersiz olduklarını ortaya koymuştur. Ayrıca Olasılık öğrenme alanının öğretim programında sadece 8. sınıfta yer alması ve yukarıda da tartışıldığı gibi 8. sınıf düzeyindeki öğrencilerin sınava hazırlık aşamasında olmaları da, öğretmen adaylarını Olasılık öğrenme alanında oyun tasarlamaktan uzaklaştırmış olabilir.

Eldeki çalışmada tasarlanma amaçlarına bakıldığında matematik öğretmeni adaylarının daha çok oyunları konuların işlenmesinin ardından pekiştirme amaçlı tasarladıkları görülmektedir. Bu sonuç Uğurel ve Moralı'nın (2010) ortaöğretim matematik öğretmeni adayları ile gerçekleştirdikleri çalışmanın sonuçları ile benzerlik göstermektedir. Bizzat oyunu kullanarak bir konunun öğretimini gerçekleştirmek için, hem bu amaçla kullanılabilecek geliştirilmiş bir oyuna hem de detaylı bir ders planına ihtiyaç duyulacağı söylenebilir. Ancak öğretmen adaylarının henüz 2. sınıfta öğrenim gördükleri ve alan eğitimi derslerinin tamamını alamadıkları düşünülürse bunu gerçekleştirmelerinin zor olduğu düşünülebilir.

Araştırma kapsamında ortaokul matematik öğretmenleri tarafından hazırlanan oyunlara katılım durumuna bakıldığında genellikle tüm sınıfın katılabileceği veya birkaç kişi ile oynanan ancak sınıf ortamına da uyarlanabilen oyunların tercih edildiği görülmüştür. Araştırmanın sonuçlarına göre tüm sınıfın katılacağı oyunların doğal olarak sınıf ortamında oynanacak şekilde tasarlanmışken; birkaç kişi veya tüm sınıf oynanabilen oyunların ise sınıf içinde oynanabileceği gibi sınıf dışında evde vs. de oynanabileceği anlaşılmaktadır.

Uğurel ve Moralı'nın (2010) çalışmalarına katılan aday matematik öğretmenlerinin az sayıda oyun örneği bilmeleri, oyunları tanıma oranlarının düşüklügü ve matematik derslerini oyunlarla ilişkilendirme konusundaki eksiklikleri onları nitelikli oyun ortaya koymaktan alıkoymuştur. Buna karşın bu araştırmaya katılan öğretmen adaylarına "Oyunla Matematik Öğretimi”" dersinde ilgili konular hakkında detaylı bilgiler verilmesinin de etkisiyle, nitelikli ve işlevsel oyunlar ortaya koymayı başarabilmişlerdir.

$\mathrm{Bu}$ çalışmada öğretmen adaylarının tasarladıkları matematik derslerinde kullanabilecek oyunlar ele alınmıştır. İleride bu oyunların gerçek sınıf ortamlarında uygulanmasının sonuçlarını ele alan çalışmaların yapılması, oyunların etkililiğine dair sonuçları da ortaya çıkarabilir. Ayrıca bu çalışmada hiç bir öğretmen adayının oyun tasarlamadığı Olasılık öğrenme alanında yer alan kazanımların öğretimi için, Kakuzu gibi hazır kutu oyunlarından yararlanılabileceği gibi, oyun geliştirme çalışmalarına yer verilebilir. Bunun içinse eğitim fakültelerinde "Oyunla Matematik 
Öğretimi” dersi kapsamında öğretmen adaylarına Olasılık öğrenme alanına yönelik oyunlardan örnekler sunulabilir. Bunun yanında Olasılık da dahil diğer tüm öğrenme alanlarında sadece pekiştirme değil öğretim amaçlı oyun örnekleri de sunulması önerilmektedir.

\section{KAYNAKÇA}

Abrams, L. (2008). The effect of computer mathematics games on elementary and middle school students' mathematics motivation and achievement. (Unpublished Doctoral Thesis). Capella University. Minnesota.

Açış, Y. B., \& Ayverdi, L. (2020). The effect of the box games on attention and creativity of gifted and talented students. Erciyes Journal of Education, 4(2), 47-67.

Akandere, M. (2006). Eğitici okul oyunları (Geliştirilmiş 2. Baskı). Ankara: Nobel Yayıncılık.

Akın, F. A. ve Atıcı, B. (2015). Oyun tabanlı öğrenme ortamlarının öğrenci başarısına ve görüşlerine etkisi. Turkish Journal of Educational Studies, 2(2), 75-102.

Aksoy, N. C. ve Kaleli Yılmaz, G. (2011). Kesirler konusunda uygulanan oyun destekli öğretimin altıncı sınıf öğrencilerinin matematiğe yönelik tutumlarına etkisi. Bayburt Üniversitesi Ĕ̈itim Fakültesi Dergisi, 6(3), 105-117.

Ata, A. (2013). Öğretmen adaylarının olasılık konusuna ilişkin kavramsal ve işlemsel bilgi düzeylerinin incelenmesi. (Yayınlanmamış Yüksek Lisans Tezi). Eskişehir Osmangazi Üniversitesi Eğitim Bilimleri Enstitüsü. Eskişehir.

Başün, A. R. ve Doğan, M. (2020). Matematik eğitiminde uygulanan oyunla öğretimin akademik başarı ve kalıılığa etkisi. Disiplinlerarası Ĕ̆itim Araştırmaları Dergisi, 4(7), 155-167.

Başün, A. R. ve Doğan, M. (2017, Ekim). Çarpanlar ve katlar alt öğrenme alanın oyunla ögretimine yönelik öğrenci görüşleri. 3. Uluslararası Sosyal Bilimler Sempozyumunda sunulan bildiri, Kahramanmaraş Sütçü İmam Üniversitesi, Kahramanmaraş.

Bayram, B. (2015). 8. sınıf TC inkllap tarihi ve Atatürkçülük dersinde harita üzerinde oynanan kutu oyunları kullanımının öğrenci başarısı ve hatırda tutmaya etkisi. (Yayınlanmamış Yüksek Lisans Tezi). Adnan Menderes Üniversitesi Sosyal Bilimler Enstitüsü. Aydın.

Beyhan, N. ve Tural, H. (2007). İlköğretim matematik öğretiminde oyunla öğretimin erişiye etkisi. Dokuz Eylül Üniversitesi Buca Eğitim Fakültesi Dergisi, 21, 37-48.

Creswell, J. W. (2013). Araştırma deseni: Nitel, nicel ve karma yöntem yaklaşımları (Çev. S. B. Demir). Ankara: Eğiten Kitap.

Çankaya, S. ve Karamete, A. (2008). Eğitsel bilgisayar oyunlarının öğrencilerin matematik dersine ve eğitsel bilgisayar oyunlarına yönelik tutumlarına etkisi. Mersin Üniversitesi Eğitim Fakültesi Dergisi, 4(2), 115-127.

de Freitas, S. (2018). Are games effective learning tools? A review of educational games. Educational Technology \& Society, 21(2), 74-84.

Deterding, S., Sicart, M., Nacke, L., O’Hara, K., \& Dixon, D. (2011). Gamification: Using game-design elements in nongaming contexts. Proceedings of CHI EA '11, ACM Press, $2425-2428$.

Doğan, Z. ve Sönmez, D. (2019) İlkokul öğretmenlerinin matematiksel oyunların matematik derslerinde kullanılması süreçlerine ilişkin görüşleri. Marmara Üniversitesi Atatürk Eğitim Fakültesi Ĕgitim Bilimleri Dergisi, 50(50), 96-108. 
Donmuş, V. (2012). Ingilizce öğrenmede eğitsel bilgisayar oyunu kullanmanın erişiye, kalıcllı̆ga ve motivasyona etkisi. (Yayınlanmamış Yüksek Lisans Tezi). Fırat Üniversitesi Eğitim Bilimleri Enstitüsü. Elazığ.

Duran, M., \& Kaplan A. (2014). Matematiksel kavramlarla geliştirilen "kelimeden kavrama" oyununa ilişkin öğrenci-öğretmen görüşleri. Journal of Kirsehir Education Faculty, 15(2), 155-173.

Durkin, K., \& Barber, B. (2002). Not so doomed: Computer game play and positive adolescent development. Journal of applied developmental psychology, 23(4), 373-392.

Emin, O. (2019, Mayıs). Geleneksel çocuk oyunlarının çocukların eğitimi üzerindeki etkisi. 24. Uluslararası Türk Kültürü Sempozyumu ve Karma Türk Sanatları Sergisinde sunulan bildiri, Makedonya.

Fırat, S. (2011). Bilgisayar destekli ĕgitsel oyunlarla gerçekleştirilen matematik öğretiminin kavramsal öğrenmeye etkisi. (Yayınlanmamış Yüksek Lisans Tezi). Adıyaman Üniversitesi Fen Bilimleri Enstitüsü. Adıyaman.

Girmen, P. (2012). Eskişehir folklorunda çocuk oyunları ve bu oyunların yaşam becerisi kazandırmadaki rolü. Millî Folklor, 24(95), 263-273.

Gobet, F., de Voogt, A., \& Retschitzki, J. (2004). Moves in mind: The psychology of board games. Hove: Psychology Press.

Gökbulut, Y. ve Yücel Yumuşak, E. (2014). Oyun destekli matematik öğretiminin 4. sınıf kesirler konusundaki erişi ve kalıcılığa etkisi. Electronic Turkish Studies, 9(2), 673-689.

Gürbüz, R., Gülburnu, M. ve Şahin, S. (2017). Oyun destekli kesir öğretimine ilişkin öğretmen görüşleri: Video destekli bir çalışma. Journal of Social Sciences/Sosyal Bilimler Dergisi, 9(25), 98-132.

Hacısalihoğlu Karadeniz, M. (2017). Geleneksel çocuk oyunlarının matematiğe uyarlanması ve uygulanması sürecindeki kazanım ve problemlere genel bir bakış. Kastamonu Eğitim Dergisi, 25(6), 2245-2262.

Hacısalihoğlu Karadeniz, M. (2018). Geleneksel çocuk oyunlarıyla matematik öğretmek: Matematik mi oyun? Oyun mu matematik?. O. Köse ve E. İslamoğlu (Ed.), Edebiyat, eğitim, sanat ve iktisat: Modern dönemde (s. 269-300) içinde. Ankara: Berikan Yayınevi.

Horzum, M. B. (2011). İlköğretim öğrencilerinin bilgisayar oyunu bağımlılığı düzeylerinin çeşitli değişkenlere göre incelenmesi. Eğitim ve Bilim, 36(159), 56-68.

Jimenez Silva, M., White Taylor, J. D., \& Gomez, C. (2010). Opening opportunities through math board games: Collaboration between schools and a teacher education program. Issues in the Undergraduate Mathematics Preparation of School Teachers, 2, 18.

Kablan, Z. (2010). The effect of using exercise-based computer games during the process of learning on academic achievement among education majors. Educational Sciences: Theory and Practice, 10(1), 351-364.

Kinchin, I. M. (2018) Having fun, playing games and learning biology. Journal of Biological Education, 52(2), 121-121.

Kirriemuir, J., \& McFarlane, A. (2004). Literature review in games and learning. (Report 8). Futurelab series. Retrived from http://admin.futurelab.org.uk/resources/documents /lit_reviews/Games_Review.pdf 
Linehan, C., Kirman, B., Lawson, S., \& Chan, G. (2011) Practical, appropriate, empiricallyvalidated guidelines for designing educational games. Proceedings of the SIGCHI Conference on Human Factors in Computing Systems, 1979-1988.

Marklund, B. B., \& Alklind Taylor, A. S. (2016). Educational games in practice: The challenges involved in conducting a game-based curriculum. Electronic Journal of eLearning, 14(2), 122-135.

Orhan, S. (2018). Oyun eğitiminin sedanter çocukların dikkat ve konsantrasyon düzeyi ile el-göz koordinasyonuna etkisi. (Yayınlanmamış Yüksek Lisans Tezi). Fırat Üniversitesi Sağlık Bilimleri Enstitüsü. Elazı̆̆.

Özata, M. ve Coşkuntuncel, O. (2019). Ortaokul matematik öğretmenlerinin matematik öğretiminde eğitsel matematik oyunlarının kullanımına ilişkin görüşleri. Mersin University Journal of the Faculty of Education, 15(3), 662-683.

Pratt, D. (2000). Making sense of the total of two dice. Journal for Research in Mathematics Education, 31(5), 602-625.

Prensky, M. (2001). Fun, play and games: What makes games engaging. Digital Game-Based Learning, 11-16. New York: McGraw-Hill.

Risdiyanti, I., Prahmana, R. C. I., \& Shahrill, M. (2019). The learning trajectory of social arithmetic using an Indonesian traditional game. Elementary Education Online, 18(4), 2094-2108.

Salen, K., \& Zimmerman, E. (2003). Rules of play: Game design fundamentals. Cambridge: MIT Press.

Sayg1, E. ve Alkaş Ulusoy Ç. (2019). İlköğretim matematik öğretmen adaylarının hafiza oyunları ile hafiza oyunlarının matematik öğretimine katkısına ilişkin görüşleri. Bolu Abant İzzet Baysal Üniversitesi Ĕgitim Fakültesi Dergisi, 19(1), 331- 345.

Soylu,Y. (2001). Matematik derslerinin ögretiminde (1. devre 1,2,3,4,5. sinif) başvurulabilecek eğitici ögretici oyunlar. (Yayınlanmamış Yüksek Lisans Tezi). Atatürk Üniversitesi Fen Bilimleri Enstitüsü. Erzurum.

Şahin, H. B. (2016). Eğitsel bilgisayar oyunlarlyla destekli matematik ögretiminin öğrencilerin akademik başarılarına ve duyuşsal özelliklerine etkisi. (Yayınlanmamış Yüksek Lisans Tezi). Osmangazi Üniversitesi Eğitim Bilimleri Enstitüsü. Eskişehir.

Treher, E. N. (2011). Learning with board games: Tools for learning and retention. MN: The Learning Key Inc.

Topçu, H., Küçük, S. ve Göktaş, Y. (2014). Sınıf öğretmeni adaylarının ilköğretim matematik öğretiminde eğitsel bilgisayar oyunlarının kullanımına yönelik görüşleri. Turkish Journal of Computer and Mathematics Education, 5(2), 119-136.

Tucker, S. I. (2014). REFractions: The representing equivalent fractions game. Australian Primary Mathematics Classroom, 19(1), 29-34.

Tuğrul, B., Ertürk, H. G., Özen Altınkaynak, Ş. ve Güneş, G. (2014). Oyunun üç kuşaktaki değişimi. The Journal of Academic Social Science Studies, 27, 1-16.

Tural, H. (2005). Illköğretim matematik ögretiminde oyun ve etkinliklerle öğretimin erişi ve tutuma etkisi. (Yayınlanmamış Yüksek Lisans Tezi). Dokuz Eylül Üniversitesi Eğitim Bilimleri Enstitüsü. İzmir.

Tüzün, H., Arkun, S., Bayırtepe Yağız, E., Kurt, F., \& Yermeydan Uğur, B. (2008). Evaluation of computer games for learning about mathematical functions. Journal of Educational Technology, 5(2), 64-72. 
Uğurel, I. ve Moralı, S. (2008). Matematik ve oyun etkileşimi. Gazi University Journal of Gazi Educational Faculty, 28(3), 75-98.

Uğurel, I. ve Moralı, S. (2010). Ortaöğretim matematik derslerinde oyunların kullanılabilirliği. Milli Eğitim Dergisi, 40(185), 328-352.

Umay, A. (2002). Öteki matematik. Hacettepe Üniversitesi Eğitim Fakültesi Dergisi, 23, 275281.

Ulutaş, A. (2011). Okul öncesi dönemde drama ve oyunun önemi. Adlyaman Üniversitesi Sosyal Bilimler Enstitüsü Dergisi, 4(6), 232-242.

Usta, N., Işık, A. D., Şahan, G., Genç, S., Taş, F., Gülay, G., ve diğerleri. (2017). The opinions of pre-service teachers on the usage of games in mathematics teaching. International Journal of Social Sciences and Education Research, 3(1), 328-344.

Usta, N., Işık, A. D., Taş, F., Gülay, G., Şahan, G., Genç, S., ve diğerleri. (2018). Oyunlarla matematik öğretiminin ortaokul 7. sınıf öğrencilerinin matematik başarısına etkisi. Elementary Education Online, 17(4), 1972-1987.

Uygun, N. ve Hakkoymaz, S. (2019). Hakeke: Gaziantep geleneksel çocuk oyunları aracıllğıyla Türkçe ve matematik ögretimi. İstanbul: Hiperyayın.

Vos, N., Meijden, H., \& Denessen, D. (2011). Effects of constructing versus playing an educational game on student motivation and deep learning strategy use. Computers \& Education, 56, 127-137.

Yıldız Durak, H. (2019). Matematik öğretmenliği öğretmen adaylarının oyun algıları ve oyunların matematik eğitimine entegrasyonu ile ilgili görüşlerinin incelenmesi. Proceedings of ERPA International Congresses on Education, 122-126.

Yıldız Durak, H. ve Karaoğlan Yılmaz, F. G. (2019). Öğretmen adaylarının matematik öğretimine yönelik eğitsel dijital oyun tasarımlarının ve tasarım sürecine ilişkin görüşlerinin incelenmesi. Ege Eğitim Dergisi, 20(1), 262-278.

\section{EXTENDED ABSTRACT}

\section{Introduction}

Games are important for children and they can come up in different formats: board/card games, computer games, traditional games, sports games, folk dances, theater games etc. Games should not be seen only as a means of entertainment for children, and the important link between play and learning should not be ignored by adults (Tuğrul, Ertürk, Özen Altınkaynak and Güneş, 2014). Whilst playing games, children automatically acquire some behaviours, knowledge and skills (Girmen, 2012). In addition, games provide personal learning experiences that are not possible in conventional learning environments (Vos, Meijden, \& Denessen, 2011). Teaching a difficult lesson such as mathematics with games can be effective in overcoming the fears of students, overcoming their prejudices and motivating them (Uygun and Hakkoymaz, 2019). There are many studies on the use of games in mathematics teaching, however, relatively few examples focussed on games integrated into mathematics learning environments (Linehan, Kirman, Lawson, \& Chan, 2011).

Therefore, in this study, secondary school mathematics teacher candidates were asked to design games to teach mathematics. Then, the designed games were classified in terms of game types, the place where the game is played, class level, learning area, teaching purposes and the number of players. A further aim of the research was to present examples of games that can be used in secondary school mathematics lessons. Therefore, different game samples in accordance 
with grade levels, game types, learning areas, game places and aims of the game, are presented in the article.

\section{Methods}

The research employed the case study method and the sample of the research consisted of 38 teacher candidates who took the "Teaching Mathematics with games" course during the second year of Secondary Mathematics Teaching Program in the 2019-2020 Spring term. The games designed by the students constituted the data of the research. Once students have been informed about teaching mathematics with games, they were asked to design games for teaching an outcome or a unit or for practice purposes. They were expected to prepare detailed guides for these games and were free to choose the types of games (traditional games, computer games, intelligence and strategy games, board games, gamification), grade level $(5,6,7$ or 8 th grade). Descriptive analysis technique was used to analyse the data and the MAXQDA Analytics Pro 2018 program was used in the analysis phase. The data was classified in terms of game types, grade level, learning area and sub-learning area, whether the game was used for reinforcement or teaching purposes, and the place in which the game will be played.

\section{Results}

The results showed that 37 out of 38 students designed their games to reinforce a topic. The board/card games $(\mathrm{f}=31)$ were mostly preferred whereas four participants adapted traditional games to mathematics teaching, 2 pre-service teachers included gamification elements instead of designing games, and 1 pre-service teacher designed a computer game.

The games addressed the following grades: 5 th $(\mathrm{f}=11)$, 6th $(\mathrm{f}=13), 7$ th $(\mathrm{f}=12)$, ad fewer games were designed for the 8th grade $(\mathrm{f}=7)$. In terms of learning areas, the majority of the games $(\mathrm{f}=26)$ were created for the to teach numbers and operations. There was only one game designed for the data processing, and no games have been designed to teach probability

Only two of the games were designed to be played individually, nearly half of them were designed to be played by the whole class ( $\mathrm{f}=15$ ). Most games (22) were designed to be played both inside and outside classroom.

\section{Discussion and Conclusion}

Findings shows that teacher candidates designed the games mostly to reinforce the teaching of a particular subject. This result is in parallel with the results of Ugurel and Moralı's (2010) study. In addition, the students mostly used cardboards as they were easily accessible material to design board games. It is also because board games have well-defined rules (Gobet, de Voogt, \& Retschitzki, 2004). Some pre-service teachers preferred board/card games or chose to adapt the games (wheel of fortune, bingo, taboo, etc.) that are well-known by everyone. Some of them preferred to design an original game suitable for the topic they chose.

Only few games were designed for 8th graders compared to other grade levels. This may be related to the fact that 8 th grade students are final year secondary students who study for high school entrance exams. Although it is possible to benefit from games in the teaching of every mathematics subject, students mostly preferred the "numbers and operations" sub-learning area when designing games.

Finally, according to the results of the research, the games that the whole class will participate in are naturally designed to be played in the classroom environment; games that can be played with a few people or with the whole class can be played not only in the classroom but also outside the classroom. 